\title{
Review \\ Plant-Based Bioinsecticides for Mosquito Control: Impact on Insecticide Resistance and Disease Transmission
}

\author{
Meryem Ş. Şengül Demirak *(i) and Emel Canpolat
}

check for updates

Citation: Şengül Demirak, M.Ş.; Canpolat, E. Plant-Based

Bioinsecticides for Mosquito Control: Impact on Insecticide Resistance and Disease Transmission. Insects 2022, 13, 162. https://doi.org/10.3390/ insects13020162

Academic Editor: Rosemary S. Lees

Received: 23 December 2021

Accepted: 31 January 2022

Published: 3 February 2022

Publisher's Note: MDPI stays neutral with regard to jurisdictional claims in published maps and institutional affiliations.

Copyright: (C) 2022 by the authors. Licensee MDPI, Basel, Switzerland. This article is an open access article distributed under the terms and conditions of the Creative Commons Attribution (CC BY) license (https:// creativecommons.org/licenses/by/ $4.0 /)$.
Department of Molecular Biology and Genetics, Tokat Gaziosmanpaşa University, Tokat 60150, Turkey; emel.canpolat@gop.edu.tr

* Correspondence: senay.sengul@gop.edu.tr

Simple Summary: Mosquito-borne diseases cause millions of deaths each year. There has been an increase in the use of insecticides to combat disease transmission caused by mosquitoes. Synthetic insecticides have been effectively used to protect humans from mosquito bites through insecticidetreated mosquito nets, fabrics, and indoor sprays. Despite the considerable progress made in reducing mosquito borne diseases, extensive usage of insecticides has caused serious health problems to humans and animals, insecticide resistance or insensitivity in mosquitoes, and environmental damage. A success in the fight with mosquito disease transmission can only be accomplished by adequate and effective implementation of insecticide resistance monitoring and management programs globally. For this purpose, extensive research focuses on exploring insecticide resistance mechanisms in mosquitoes and how they get resistant to chemical applications over time. The search also focuses on novel compounds that are more effective, safer, and eco-friendly for improved management of mosquito vectors. In this review, we provide the current literature on the synthetic insecticides and how mosquitoes develop resistance to them, with further emphasis on bioinsecticides that could replace conventional synthetic insecticides. In this context, plant-based compounds are explained in detail with their potential applications to control mosquitoes.

Abstract: The use of synthetic insecticides has been a solution to reduce mosquito-borne disease transmission for decades. Currently, no single intervention is sufficient to reduce the global disease burden caused by mosquitoes. Problems associated with extensive usage of synthetic compounds have increased substantially which makes mosquito-borne disease elimination and prevention more difficult over the years. Thus, it is crucial that much safer and effective mosquito control strategies are developed. Natural compounds from plants have been efficiently used to fight insect pests for a long time. Plant-based bioinsecticides are now considered a much safer and less toxic alternative to synthetic compounds. Here, we discuss candidate plant-based compounds that show larvicidal, adulticidal, and repellent properties. Our discussion also includes their mode of action and potential impact in mosquito disease transmission and circumvention of resistance. This review improves our knowledge on plant-based bioinsecticides and the potential for the development of state-of-the-art mosquito control strategies.

Keywords: bioinsecticide; disease transmission; insecticide-resistance; mosquito-borne disease; mosquito control; natural compounds; phytochemical

\section{Introduction}

Mosquitoes have been a big burden to human health for a long time. These insects can invade in different geographic locations and new habitats through global trade and travel [1] which causes millions of people be at risk of the diseases they transmit. In 2019, an estimated 229 million cases and 409 thousand deaths for malaria and 56 million cases for dengue have been reported worldwide [2,3]. While malaria case incidences were reported to decline, the number of malaria endemic countries has increased in the 
period 2000-2019 [2]. The global incidence of dengue is thought to be increased about thirty times over the last fifty years with emergencies in new countries [4-6]. A recent study also indicates that mosquito species will continue to spread globally over the coming decades, which may cause about $50 \%$ of the world's population at the risk of mosquito-borne viral disease transmission by 2050 [7]. Even a more serious problem is at our doorstep as the climate change is expected to increase the burden of mosquito-borne diseases despite the ongoing disease control interventions [8,9].

The most common way of keeping mosquitoes away from their human hosts is to use synthetic insecticides in mosquito nets, fabrics, and indoor sprays. The usage of chemical strategies has brought hope in controlling disease transmission in endemic regions, but emergence of insecticide resistance has been a major problem in reducing the disease burden. The uncontrolled usage of insecticides has led to reemergence and increase in mosquito populations over the years. Between the years 2010-2019, about 28 malaria endemic countries (out of 82) have detected resistance to all four classes of the most commonly used insecticides, and 73 have detected resistance to at least one insecticide class, an issue that continues to increase globally [2]. Thus, insecticide resistance is now considered a serious threat to control mosquito invasion and disease transmission. It is essential that the methods for insecticide monitoring in mosquito populations and interpretation of results are performed adequately, effectively and in a timely manner for improving mosquito control $[10,11]$.

Current research on mosquito control is now focused on understanding the mosquito resistance to synthetic insecticides and developing novel strategies to overcome the resistance issues. Natural compounds that are more effective and less toxic than the synthetic ones continue to get more attention in the research community. The use of bioinsecticides, composed of botanical or plant-based compounds, has been a perfect alternative due to their minimal hazardous effects on human health and environment. In this review, we provide current knowledge on synthetic insecticides that are actively used in mosquito control and how they impact prevalence of insecticide resistance in mosquitoes. Major plant-based insecticides, their mode of action and the research about their potential mosquitocidal activity are discussed. A comprehensive understanding of how biochemical compounds can be advantageous to synthetic ones and how we can circumvent insecticide resistance issues in the fight with mosquito-borne disease transmission is provided.

\section{Insecticide-Based Mosquito Control Strategies}

Insecticide-based mosquito control plays an important role in efforts to reduce the transmission of mosquito-borne diseases worldwide. Two core insecticidal interventions are in use to control mosquitoes: deployment of insecticide-treated mosquito nets (ITNs) and indoor residual spraying (IRS) of insecticides [10]. These interventions have been effectively used to kill mosquitoes or interfere with their host-seeking behavior to prevent disease transmission worldwide [12-20]. The global malaria cases and malaria death rates have declined about $18 \%$ and $48 \%$, respectively, between the years 2000 and 2015, and 70\% reduction in malaria cases in sub-Saharan Africa was attributed to ITNs, and $10 \%$ reduction was due to IRS [21].

Four classes of insecticides are mostly used in mosquito control programs which include pyrethroids (e.g., deltamethrin, permethrin, cypermethrin, lambda-cyhalothrin), organochlorines (e.g., DTT), organophosphates (e.g., malathion, fenitrothion), and carbamates (e.g., propoxur, bendiocarb) [10] (Figure 1). Most synthetic insecticides have physiological or behavioral impact on mosquitoes (Figure 1), and predominantly target the central nervous system of insects. Among them, pyrethroids are the most widely used insecticides for IRS and the only synthetic insecticide currently used in ITNs and fabrics, with irritant or repellent activity on mosquitoes and less mammalian toxicity [2]. They disrupt the voltage-gated sodium channels in neuronal membranes [22]. When pyrethroids bind an open channel, they prevent its closure, thus leading to a prolonged action potential 
or disruption of electrical signaling in the nervous system [23-25]. This causes continuous nerve excitation and paralysis (or knockdown) of the insect and eventually its death [26].

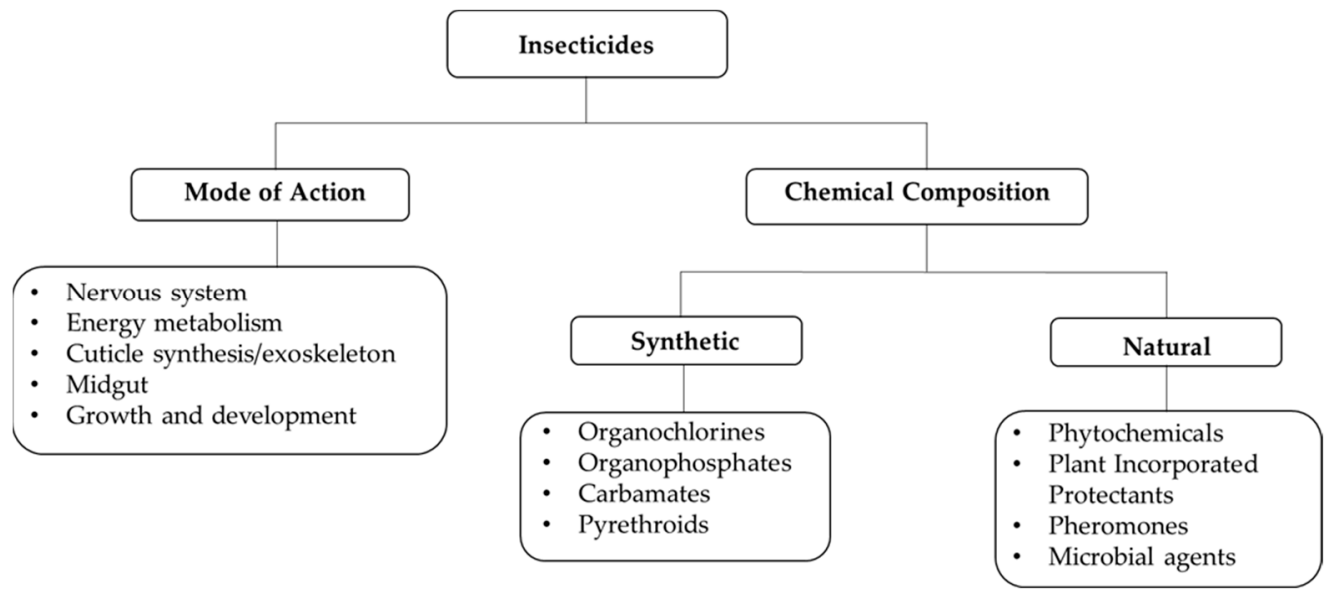

Figure 1. Classification of insecticides based on mode of action and chemical composition.

While pyrethroids have been effectively used in ITNs to control mosquitoes for a long time, prevalence of pyrethroid resistance in mosquito species causes a major problem to combat disease transmission worldwide [27-29]. Like pyrethroids, some organochlorines are also inhibitors of the insect's voltage-gated sodium channels. Dichlorodiphenyltrichloroethane (DDT) is an example that targets sodium channels, and it is the first and the most commonly used synthetic insecticide of organochlorine in residual spraying. Its low cost and high effectiveness have made it a favorable chemical for indoor wall spraying. However, resistance developed to DDT in various mosquito species and its toxic effects on humans and non-target organisms have imposed limitations or restrictions in its usage $[30,31]$. Other organochlorines (such as cyclodienes, dieldrin and fipronil) target $\gamma$-amino butyric acid (GABA) receptors, which are hetero-multimeric gated chloride channels in the insect's central nervous system [32]. Cyclodiene insecticides act as neurotoxicants and block the GABA receptors causing hyper-excitation of the central nervous system, convulsions, and eventually death of insects [33-35]. Organophosphates (OP) and carbamates are two other insecticides sharing similar mode of action. They inhibit acetylcholinesterase (AChE) enzyme, preventing breakdown of the neurotransmitter acetylcholine, resulting in neuromuscular overstimulation and death of insects [36-38]. Due to pyrethroid and DDT resistance issues worldwide, they have been used as alternative insecticides in IRS, but they have a shorter residual effectiveness, high toxicity to mammals, and are more costly compared to the others that limit their persistent long-term usage.

\section{Insecticide Resistance in Mosquitoes}

Short after its first usage in California in 1945, the resistance of mosquitoes to DDT was reported $[39,40]$. Since then, insecticidal resistance in mosquitoes has been reported, with a substantial increase between 2010 and 2016 [10]. In these years, insecticide resistance was found to be widespread in Anopheles vectors in malaria endemic African regions and insecticide resistance frequency has changed over time [10]. Understanding pyrethroid resistance development in Anopheles mosquitoes is particularly important because its prevalence can disable pyrethroid-treated ITN-based interventions, which are used successfully for malaria control [41,42]. Pyrethroid resistance was determined to be very high in the WHO African Region (78\%), Eastern Mediterranean Region (70\%), and in the South-East Asia Region (38\%), Western Pacific Region (51\%), but was lower in the Region of the Americas (20\%). The incidence of organochlorine resistance was also similar in all WHO regions (60-70\%). Carbamate resistance prevalence was between $22 \%$ and $54 \%$, and organophosphate resistance prevalence varied widely across regions, 14\% in the WHO African Region and 65\% 
in the WHO Western Pacific Region [10]. While resistance frequencies are generally high in most of the endemic regions, those with lower resistance frequencies could be an indication of recent gain of resistance or selection for resistant populations to insecticides [43].

Despite effective use of insecticide-based mosquito control strategies for decades, their prolonged usage is challenged by high cost, toxicity and, more importantly, the development of resistance to the synthetic insecticides. Insecticide resistance is mostly inferred to the ability of insects to survive exposure to a standard dose of insecticide, owing to physiological or behavioral adaptation [44]. Resistance can be developed due to misusage or overdose usage of insecticides and selection pressure on the insect populations [45]. The question "when does the resistance emerge?" depends on the mechanism of resistance, known susceptibility, cost effectiveness and availability [45]. Various resistance mechanisms have been observed in mosquitoes: changes in their metabolism (changes in enzymes leading due rapid detoxification of insecticides), alterations in target-sites (prevention of insecticides to their target sites), penetration resistance (cuticle barrier diminishes insecticide penetration) and behavioral resistance (changes in their response to insecticidal effect) [46-49]. These mechanisms can be determined by using bioassays, biochemical assays, and molecular techniques through assessment of resistance alleles, analyzing whether metabolic enzymes are upregulated, or determination of the percent mortality rate upon exposure to a given insecticide.

In mosquitoes, alterations of target site nerve receptors (e.g., mutations in $k d r, R d l$ and $A c e-1 R$ genes) and detoxification due to increased or modified enzyme activities (e.g., monooxygenases (P450s), glutathione-S-transferases and carboxylesterases) are the two major mechanisms responsible for insecticide resistance. According to the insecticide resistance monitoring data for 2010 to 2016 , almost $70 \%$ of the assays to test resistance mechanisms included detection of the presence or absence of target-site mutations and their frequencies in WHO regions [10]. Target site alterations in mosquitoes involve knockdown resistance $(k d r)$ mutations (L1014F or L1014S) in the voltage-gated sodium channel gene which causes inability of the insecticides to bind their cognate receptors [50-55]. Occurrence of $k d r$ mutations causes insensitivity to pyrethroids and DDT [56,57]. A $k d r$-resistant strain of An. gambiae has shown to be less affected by pyrethroids than the susceptible strain [58]. In the last few decades, $k d r$ resistance mutations in different mosquito populations have expanded significantly which restricts pyrethroid usage in mosquito control [59]. Another target-site mutation, the $\mathrm{AChE}$ gene mutation $($ Ace-1R), causes resistance to organophosphates and carbamates. In mosquitoes, a G119S mutation in the Ace-1R gene encoding $\mathrm{AChE}$ causes resistance to organophosphate and carbamate insecticides and the mutation frequency is increasing in natural mosquito populations [60-63]. A substitution mutation of alanine-to-serine/glycine (A296S/G) mutation, $R d l$, in the second transmembrane domain of the GABA receptor subunit causes resistance to organochlorine insecticides and insensitivity in mosquitoes [35,64-69].

Mosquitoes have metabolic enzymes, mainly "detoxifying enzymes" that are responsible for biodegradation of insecticides and elimination of their insecticidal effects. Upon exposure to synthetic insecticides, detoxifying enzyme activity increases (due to increased gene amplification or upregulation) which result in insecticide-resistant mosquitoes [46] Three classes of detoxifying enzymes are involved in insecticide-resistance in mosquitoes: cytochrome P450 monooxygenases (CYP), glutathione-S-transferases (GST) and carboxylcholinesterases (CCE) associated with pyrethroid, organochloride, and OP and carbamate resistances, respectively. Cytochrome P450 enzymes are involved in the metabolism of all four classes of insecticides. It is found that elevated levels of P450 activity resulted in pyrethroid resistant mosquito vectors [70-74]. Several CYPs are identified in mosquitoes and CYP overexpression is reported from insecticide resistant mosquito populations [45,59,75-77]. Knockdown of the CYP through the RNA-interference technique also showed that mosquitoes become sensitive to pyrethroids [78-80]. Glutathione S-transferases comprise a diverse family of enzymes involved in detoxification of insecticides (e.g., pyrethroids and DTT) in mosquitoes [81]. An increase in the gene expression levels of various GSTs has been 
detected in DDT-resistant and pyrethroid-resistant mosquitoes [82-88]. Additionally, a GST gene silencing study indicated an increase in the susceptibility to pyrethroid insecticide which shows that GSTs are involved in insecticide-resistance in mosquitoes [86]. Increased esterase detoxification in OP resistance has been studied most extensively in Culex mosquitoes [72,89]. These enzymes sequester the insecticide and interfere with its association with the target $\mathrm{AChE}$ by rapid binding and slow turning over of the insecticide [90]. The increase in the activity of esterases was due to overproduction of the enzymes, resulting from co-amplification of two esterase genes, est $\alpha 2$ and est $\beta 2$, in OP-resistant individuals [91,92].

It is evident that cross-resistance causes major issues in the management of insecticide resistance through the approaches discussed above. These mechanisms can cause resistance to more than one class of insecticide (with similar mode of action) due to prolonged and intensive usage of these chemicals. For example, Culex mosquitoes that are resistant to a pyrethroid insecticide also show resistance to OP and other insecticides [93,94]. Pyrethroidresistant Anopheline mosquitoes also show resistance to OPs due to constitutively elevated P450 levels leading to cross-resistance [95]. Moreover, insecticide resistance is genetically mediated and can be fixed in mosquito populations in such that individuals with the resistance gene will probably have a selective advantage in the presence of the insecticide $[96,97]$. Furthermore, mosquitoes that survive insecticide exposures possibly have the chance of passing those traits to their offspring which causes an increase in the percentage of resistant individuals in the next generations in those populations [48]. If resistance gene frequency increases in the populations, this can cause more resistant individuals to circumvent insecticidal exposures. Taken together, the emergence and spread of insecticide resistance, cross-resistance, and increased resistance gene frequencies in mosquito populations significantly effects mosquito-borne disease control and elimination and highlights the need for alternative strategies. There has been a great interest for safe and healthy biological control strategies and development of novel interventions to overcome problems associated with synthetic insecticides. Hence, extensive research for another class of insecticide for mosquito control, named "bioinsecticide", is an ongoing process and novel natural compounds are being investigated to replace conventional synthetic insecticides. In this review, we will focus on plant-based bioinsecticides with potential activity in mosquito control.

\section{Plant-Based Bioinsecticides}

Bioinsecticides are derived from natural products, such as bioactive compounds of plants, pheromones, and from microorganisms, such as bacteria, fungi, virus, or protozoan. There are four major classes of bioinsecticides based on their nature of origin: phytochemicals, microbial pesticides, plant-incorporated protectants (PIPs), and pheromones [98] (Figure 1). They have been effectively used in pest management and generation of sustainable agricultural products $[99,100]$. They are less toxic, target-specific, highly effective in small quantities and biodegradable, which makes them excellent alternatives to synthetic compounds. More importantly, mosquitoes are developing resistance to synthetic compounds, a burden that needs to be resolved for successful mosquito disease control. Since biopesticides induce less insect resistance [101,102], most studies now focus on discovery of candidate natural compounds with potential effects on mosquitoes to combat mosquito-borne disease transmission.

Plants have evolved to develop many defensive chemical compounds against pathogenic microorganisms and insects. These biologically active chemical compounds, referred to as "phytochemicals", function as repellents, toxins, feeding deterrents, and growth regulators against insects [103]. Various parts of higher plants (leaves, roots, stems, seeds, barks, fruits, peels of fruit and resin), the whole body of little herbs, or mixture of different plants can be used for an effective plant-based insecticide. The activity of a phytochemical can change significantly depending on the plant species, plant part and its age, polarity of solvents used during extraction procedures and mosquito species [104]. Phytochemicals show 
their effects through targeting important cell components and affecting insect physiology in different ways; via inhibition of AChE and GABA-gated chloride channel activity, disruption of sodium-potassium ion exchange and nerve cell membrane action, blocking calcium channels, and activation of nicotinic acetylcholine receptors and octopamine receptors [105]. Moreover, phytochemicals can cause cellular destruction of epithelial cells in the midgut of mosquitoes and affect metamorphosis [106,107].

Several phytochemicals have been reported for their mosquitocidal activities [104,108]. These chemical compounds are mostly secondary metabolites, such as essential oils, alkaloids, phenols, terpenoids, steroids, and phenolics from different plants. Phytochemicals in plant species are diverse and discovery of those with mosquitocidal activities, which are governed by changes in expression levels of detoxifying enzymes, are of great importance to control mosquitoes. In the following sections, we provide the current knowledge on mosquitocidal plant-based compounds and their activities for a better understanding of their efficacy to prevent mosquito-borne diseases.

\section{Plant-Based Compounds and Mosquito Control}

Plant-based compounds possess larvicidal, ovicidal and repellent activities on early or adult stages of mosquitoes, affecting nervous, respiratory, endocrine, and water balance systems. Ovicidal and larvicidal effects of many plant compounds have been extensively studied since mosquitoes are immobile at these stages and they can be efficiently eliminated before they emerge as adults. Repellent compounds are effective in keeping human hosts from mosquito bites for a blood-meal. Thus, understanding the mosquito olfactory system is vital for determination of repellent compounds. Insect repellents affect the olfactory receptor neurons via modifying or blocking its response, which in turn, elicit avoidance behavior or a change in the host-seeking behavior of mosquitoes $[109,110]$. There are many plant compounds with repellent activities. Essential oils, alkaloids, and aromatic compounds from various plants are commonly used for plant-based mosquito repellents [111] and they have shown to interfere with the mosquito host-seeking behavior when applied on human skin or used as indoor spraying [112]. Insecticidal and repellent activities of four major plant metabolites (essential oils, neem, pyrethrum, alkaloids) and other plant compounds (flavonoids and rotenone) are discussed in detail (Table 1).

\subsection{Essential Oils}

Essential oils have been efficiently used against a variety of pests and for crop protection in the world and they are potential alternatives to synthetic insecticides used against mosquitoes. Essential oils are very complex natural mixtures that consist of a variety of volatile molecules, which are hydrocarbons (terpenes and sesquiterpenes), oxygenated hydrocarbons and phenylpropenes (Table 1). Essential oils are synthesized in the cytoplasm and plastids of plant cells through mevalonic acid and 2-C-methyl-erythritol 4-phosphate (MEP) pathways, respectively [113]. Essential oils target the insect nervous system and cause neurotoxic effects through several mechanisms by inhibiting the activity of AChE, and blocking octopamine receptors and GABA-gated chloride channels [114,115]. About $90 \%$ of essential oils are composed of monoterpenes, which are determined to be active ingredients for potential plant-based larvicides and cause inhibition of AChE activity in insects [116]. Monoterpenes, such as linalool, cuminaldehyde, 1,8-cineole, limonene and fenchone, cause inhibition of $\mathrm{AChE}$ and accumulation of acetylcholine in synapses and state of permanent stimulation, which results in ataxia [117,118]. According to Hideyukiu and Mitsuo [119], a mixture of monoterpenoids is a more potent inhibitor of AChE than single monoterpenoid application and acts synergistically. 
Table 1. An overview of insecticidal activity and mechanism of action of various plant-based compounds against mosquito species.

\begin{tabular}{|c|c|c|c|c|c|}
\hline Type of Botanical Product & Plant Family & Activity & Mechanism of Action & Mosquito Species & References \\
\hline $\begin{array}{c}\text { Essential Oils } \\
\text { Monoterpenes: } \\
\text { linalool, cuminaldehyde, } \\
\text { 1,8-cineole, limonene, fenchone, } \\
\text { eugenol, } \gamma \text {-terpineol, cinnamic alcohol, } \\
\text { geraniol, } \beta \text {-citronellol, } \\
P \text {-menthane-3,8 diol, } \\
\alpha \text {-pinene, } \beta \text {-pinene, } p \text {-cymene, } \\
\text { thymol, terpinolene, camphor, } \\
\text { citronellal, sabinene, carvacrol } \\
\text { Sesquiterpenes: } \\
\text { guaiol, } \alpha \text {-bisabolol, } \alpha \text {-cadinol, } \\
\text { germacrene D, } \beta \text {-caryophyllene, } \\
\text { nootkatone } \\
\text { Diterpenoids: } \\
\text { diterpene alcohol, phytol } \\
\text { Aromatic phenol } \\
\text { Coumarin }\end{array}$ & $\begin{array}{c}\text { Anacardiaceae } \\
\text { Annonaceae } \\
\text { Apiaceae } \\
\text { Asteraceae } \\
\text { Geraniaceae } \\
\text { Lamiaceae } \\
\text { Lauraceae } \\
\text { Poaceae } \\
\text { Rutaceae } \\
\text { Myrtaceae } \\
\text { Verbenaceae }\end{array}$ & $\begin{array}{l}\text { larvicidal, } \\
\text { pupaecidal, } \\
\text { ovicidal, adulticidal, } \\
\text { repellent, } \\
\text { antifeedant, } \\
\text { growth and } \\
\text { reproduction } \\
\text { inhibitors }\end{array}$ & $\begin{array}{c}\text { Inhibition of AChE } \\
\text { Blockage of GABA-gated } \\
\text { chloride channels } \\
\text { Agonist of octopamine } \\
\text { receptors }\end{array}$ & $\begin{array}{c}\text { Cx. pipiens pallens } \\
\text { Cx. quinquefasciatus } \\
\text { Cx. pipiens biotype molestus } \\
\text { Ae. aegypti } \\
\text { Ae. albopictus } \\
\text { An. gambiae } \\
\text { An. stephensi }\end{array}$ & [120-146] \\
\hline $\begin{array}{c}\text { Neem oil } \\
\text { azadirachtin, meliantriol, salannin, } \\
\text { desacetyl salannin, nimbin, desacetyl } \\
\text { nimbin, nimbidin, nimbolide, } \\
\text { deacetylgedunin, gedunin, } \\
\text { 17-hydroxyazadiradione, } \\
\text { deacetylnimbin }\end{array}$ & Meliaceae & $\begin{array}{l}\text { repellent, ovicidal, } \\
\text { larvicidal, } \\
\text { feeding deterrence, } \\
\text { fecundity suppression, } \\
\text { toxicity, } \\
\text { growth regulation, } \\
\text { oviposition deterrence }\end{array}$ & $\begin{array}{l}\text { growth inhibitors, hormonal } \\
\text { disruption (ecdysone } \\
\text { blocker), molting aberrations, } \\
\text { interference with } \\
\text { phagostimulants }\end{array}$ & $\begin{array}{c}\text { An. gambiae } \\
\text { Ae. aegypti } \\
\text { Ae. albopictus } \\
\text { An. stephensi } \\
\text { Cx. quinquefasciatus }\end{array}$ & [147-165] \\
\hline
\end{tabular}


Table 1. Cont.

\begin{tabular}{|c|c|c|c|c|c|}
\hline Type of Botanical Product & Plant Family & Activity & Mechanism of Action & Mosquito Species & References \\
\hline $\begin{array}{l}\text { Pyrethrum } \\
\text { esters of chrysanthemic acid: } \\
\text { pyrethrin I, cinerin I, jasmolin I } \\
\text { esters of pyrethric acid: } \\
\text { pyrethrin II, cinerin II, jasmolin II }\end{array}$ & Asteraceae & $\begin{array}{l}\text { repellent, } \\
\text { knock-down effect, } \\
\text { blood-feding } \\
\text { inhibition }\end{array}$ & $\begin{array}{l}\text { voltage-gated sodium } \\
\text { channel modulator }\end{array}$ & An. gambiae & [166-170] \\
\hline $\begin{array}{l}\text { Alkaloids } \\
\text { alpha-solanin } \\
\text { ricinine } \\
\text { pyridine } \\
\text { nicotine } \\
\text { diterpene } \\
\text { nornicotine } \\
\text { anabasine }\end{array}$ & $\begin{array}{l}\text { Berberidaceae } \\
\text { Fabaceae } \\
\text { Solanaceae } \\
\text { Ranunculaceae } \\
\text { Euphorbiaceae }\end{array}$ & repellent, larvicidal & $\begin{array}{l}\text { interfering with cellular and } \\
\text { physiological functions, } \\
\text { inhibition of AChE activity, } \\
\text { regulation of hormone } \\
\text { activity, toxicity, agonist of } \\
\text { acetycholine receptor }\end{array}$ & $\begin{array}{l}\text { Ae. aegypti } \\
\text { An. arabiensis } \\
\text { An. gambiae } \\
\text { Ae. albopictus } \\
\text { An. stephensi } \\
\text { Cx. pipiens }\end{array}$ & [171-181] \\
\hline Flavonoids & Zingiberaceae & larvicidal & $\begin{array}{c}\text { inhibition of AChE, } \\
\text { degradation of cell } \\
\text { membranes acting as stomach } \\
\text { poisons }\end{array}$ & Ae. aegypti & [182-184] \\
\hline Rotenone & Fabaceae & larvicidal & $\begin{array}{l}\text { inhibitor of the cellular } \\
\text { respiration system }\end{array}$ & Ae. aegypti & [185] \\
\hline
\end{tabular}


The octopaminergic system of insects is another target for essential oils that block octopamine receptors and cause acute and sub-lethal behavioral effects on insects. The increase in cyclic AMP levels, induced upon binding of octopamine to octopamine-receptors, can be inhibited by a mixture of essential oils (eugenol, $\gamma$-terpineol and cinnamic alcohol). Moreover, octopamine receptor binding is significantly reduced with low doses of eugenol alone [120,121]. Another possible target for essential oils is ligand-gated chloride channels. Essential oils consist of monoterpenes, such as linalool, methyl eugenol, estragole, citronellal, inhibit GABA-gated chloride channels by binding at the receptor site and increase the chloride anion influx into the neurons, which lead to hyper-excitation of the central nervous system, convulsions, and finally death of insects [122,123].

Many plant oils possess ovicidal, larvicidal, pupaecidal and repellent activities against various mosquito species, some of which will be discussed below. Essential oils of plants from the Lamiaceae, Poaceae, Rutaceae and Myrtaceae families are well-known for repellent activity [103]. Essential oils obtained from citronella, lemon and eucalyptus are commercially available and recommended by the U.S. Environmental Protection Agency (US EPA) as repellent ingredients for application on the skin because of their low toxicity. For example, $P$-menthane-3,8 diol (PMD) is an active component of the lemon eucalyptus plant and responsible for the repellency in mosquitoes [124].

Most of the monoterpenes and sesquiterpenes of essential oils are known with repellent activities [125]. Among monoterpenes, $\alpha$-pinene, $\gamma$-pinene, $p$-cymene, eugenol, limonene, thymol, terpinolene, citronellol, camphor and citronellal are responsible for mosquito repellency [126,127]. Representative molecules of sesquiterpenes are guaiol, $\alpha$-bisabolol, $\alpha$-cadinol, germacrene $D, \beta$-caryophyllene and nootkatone. $\beta$-caryophyllene is known to exhibit strong repellent activity against Aedes mosquitoes [126]. Repellent and larvicidal activities of monoterpenes from the essential oils of Thymus plant against $C x$. pipiens pallens, $C x$. quinquefasciatus, and Cx. pipiens biotype molestus have been determined [128-130]. Larvicidal activities of phenolic terpenes, such as thymol and carvacrol, of Satureja species were observed against $C$. pipiens biotype molestus [131]. Moreover, repellent and larvicidal activities of carvacrol were determined in the field trials against Ae. albopictus mosquitoes in Bologna (Italy) [132]. Cinnamomum osmophloeum and Carum copticum essential oils had larvicidal activity against $C x$. quinquefasciatus and $C x$. pipiens, respectively $[107,133]$. Toxicity of $\beta$-citronellol, geraniol and linalool from Pelargonium roseum essential oil was also detected in Cx. pipiens [134]. High larvicidal and pupaecidal activities of essential oils from Cinnamomum verum, Citrus aurantifolia, Cuminum cyminum, Syzygium aromaticum, Laurus nobilis, Lippia berlandieri and Pimpinella anisum were reported from Cx. quinquefasciatus [135]. Artemisia absinthium essential oils also showed toxic effects against larval populations of Aedes, Anopheles, and Culex mosquitoes [136]. Essential oils isolated from Tagetes lucida, Lippia alba, Lippia origanoides, Eucalyptus citriodora, Cymbopogon citratus, Cymbopogon flexuosus, Citrus sinensis, Swinglea glutinosa, and Cananga odorata plants showed larvicidal activities on Ae. aegypti larvae [137]. Oviposition deterrence and ovicidal activity of some of essential oils, peppermint oil, basil oil, rosemary oil, and citronella oil from Mentha piperita, Ocimum basilicum, Rosmarinus officinalis, Cymbopogon nardus and Apium graveolens were also reported in Ae. aegypti [138]. Manh et al. [139] also showed toxicity of essential oils from Eucalyptus and Cymbopogon aromatic plants to the larvae of Ae. aegypti. Essential oils also cause toxicity at different developmental stages and have repellent activities against adult Anopheles mosquitoes [140]. Essential oils extracted from Cymbopogon proximus, Lippia multiflora and Ocimum canum had larvicidal and ovicidal activities against An. gambiae and Ae. aegypti mosquitoes [141]. Besides monoterpenes and sesquiterpenes, phytol (a diterpene alcohol) and coumarin (an aromatic phenol) were both determined to be responsible for the biting deterrence effect in Ae. aegypti [142].

Repellent activity of essential oils is generally attributed to individual chemical compounds, but synergistic effects of plant metabolites have been observed when the effect of an active compound is enhanced by other major compounds or modulated by minor compounds. The efficacy of the major compounds is enhanced by minor compounds 
through different mechanisms, which may cause higher bioreactivity compared to isolated compounds of essential oils. The synergistic effect is also observed with mixture of oils. The synergistic action of the major compounds in essential oils results in higher repellent and larvicidal activity and toxicity to insects [140,143-145]. A combination of blends assayed on An. gambiae mosquitoes indicated that blends of oils showed higher repellency compared to the individual oil used [146]. It has been also reported that essential oils composed of a mixture of active components might reduce resistance in mosquito population by acting at different target sites or with a different mode of action [139].

\subsection{Neem}

Neem-based insecticides are extensively used for protection against various pests all over the world. Neem trees, Azadirachta indica, is a member of the Meliaceae family and are originated from India and distributed throughout all South- and Southeast-Asian countries, including Pakistan, Sri Lanka, Thailand, Malaysia, and Indonesia [147]. The main product of the neem is the oil extracted from the seeds and contains at least 100 active compounds, including azadirachtin, meliantriol, salannin, desacetyl salannin, nimbin, desacetyl nimbin, nimbidin and nimbolides [148]. Limonoids are the major active compound of the neem oil and act as an insect growth inhibitor. Azadirachtin is a triterpenoid and highly oxidized limonoid, one of the most potent active compounds of the neem extract and found in higher concentrations $(0.2-0.6 \%)$ in the seeds of the neem compared to other parts of the neem tree $[149,150]$. Various isomers of azadirachtin (azadirachtin A to G) were identified and azadirachtin $\mathrm{A}$ and $\mathrm{B}$ isomers are the most abundant isomers in the plant tissues. In addition, azadirachtin $\mathrm{A}$ is the most active biological ingredient which shows insecticidal activity compared to the other analogs [151-153].

Generally, neem-based products are effective in the juvenile stages of insects. Azadirachtin is structurally similar to insect hormones known as ecdysones that are involved in the process of metamorphosis. The main mechanism of action of azadirachtin is to impair the homeostasis of insect hormones by interfering with the endocrine system. Azadirachtin acts as ecdysone blocker and causes severe growth and molting aberrations by affecting ecdysteroid and juvenile hormone titers [154]. The feeding deterrent activity of azadirachtin is mediated through azadirachtin's interference with phagostimulants that are important in normal feeding behavior of mosquitos [155].

Neem-based biopesticides have a wide range of effects against insects, such as repellency, feeding deterrence, ovicidal activity, fecundity suppression, toxicity, insect growth regulation, deterrence of egg-laying, disruption of growth and reproduction, and inhibition of metamorphosis [156-160]. Larvicidal activity of the neem oil has been reported in controlling mosquito larvae in different breeding sites under natural field conditions [161]. Ayinde et al. [162] reported the repellent and larvicidal potential of the emulsified neem seed oil formulation as a suitable alternative for commercially available insecticides against $A n$. gambiae in Nigeria. Oils of neem and karanj were also found to have larvicidal, ovicidal and oviposition deterrent activities against Ae. aegypti and Ae. albopictus mosquitoes [163]. The effects of the neem limonoids azadirachtin, salannin, deacetylgedunin, gedunin, 17-hydroxyazadiradione and deacetylnimbin were analyzed, and azadirachtin, salannin and deacetylgedunin showed the highest larvicidal activity against An. stephensi [164]. Larval mortality and repellent activity were also achieved from neem essential oils against An. gambiae [162]. A neem extract, neemarin, also showed significant mortality rates at larvae, pupae, and adult stages of $C x$. quinquefasciatus and An. stephensi, where the former showed lower mortality rates [165].

\subsection{Pyrethrum}

Pyrethrum is a plant-based insecticide obtained from flower heads of Tanacetum cinerariifolium. Pyrethrum extract is composed of six active ingredients derived from esters of chrysanthemic acid: pyrethrin I, cinerin I, and jasmolin I, and esters of pyrethric acid: pyrethrin II, cinerin II, and jasmolin II [166]. They target the nervous system of insects 
and cause neurotoxic effects through blocking the voltage-gated sodium channels in nerve axons, thereby cause hyperactivity and convulsions by a rapid knockdown effect [167]. The mode of action of pyrethrins is similar to that of DDT and many synthetic organochlorine insecticides. Thus, pyrethrins can be alternatively used instead of organophosphates and organochlorides. While it is less toxic to mammals, it has higher toxicity to fish and aquatic invertebrates. When used together with a conventional synergist, such as piperonyl butoxide (PBO), their activity is increased and harmful effects to non-target organisms are reduced [168]. The usage of natural pyrethrins in mosquito control is supported with the finding that pyrethrum had knock-down effect, repellency, and bloodfeeding inhibition in pyrethroid-resistant $A n$. gambiae strains [169]. Electroantennogram responses of pyrethrum in Ae. aegypti and An. gambiae mosquitoes were detected while no response is observed in maxillary palps, indicating that the repellency effect of pyrethrum is mediated by the olfactory systems of mosquitoes [170]. Moreover, the molecular mechanism of pyrethrum repellency was investigated and a synergistic mechanism involving dual activation of olfactory repellency pathways and voltage-gated sodium channels has been determined [170].

\subsection{Alkaloids}

Alkaloids are nitrogen-containing natural products found in bacteria, fungi, animals, and plants. They are commonly isolated from plants and found in large quantities in many members of the Berberidaceae, Fabaceae, Solanaceae, and Ranunculaceae families. The alkaloids obtained from these plants are used extensively in conventional insect repellents [171-173]. The mode of action of alkaloids varies depending on the type of alkaloids and interferes with major cellular and physiological functions by affecting AChE receptors in the nervous system, regulating hormonal activity, and causing toxicity [174]. Alkaloids are not volatile like essential oils. However, they could be used as repellents against mosquitoes by burning plants to generate an insecticidal smoke that repels insects and directly causes toxicity [124]. In Ae. aegypti, the inhibitory effect of natural alkaloids on AChE activity was determined by using molecular docking studies. Among the 25 different alkaloids tested, alpha-solanine has been found to fit into the AChE1 binding pocket and potentially be the best inhibitor of AChE1 [175].

Extracts of the castor bean (Ricinus communis, Euphorbiaceae) contain the alkaloid ricinine and have a strong insecticidal effect. It showed strong larvicidal activity against larvae of An. arabiensis [176]. Additionally, pyridine alkaloid from R. communis showed bioactivity against An. gambiae larvae and adults [177]. The larvicidal activity of alkaloids against Ae. albopictus, Cx. pipiens pallens and Ae. aegypti has also been determined [178,179]. Alkaloid from Arachis hypogaea plant also had larvicidal toxicity against An. stephensi and Ae. aegypti mosquitoes [180].

Nicotine is an alkaloid derived from tobacco plant (Nicotiana tobacco) that mostly consists of phenolic compounds, such as nicotine and diterpene. Nicotine, nornicotine and anabasine mimic the neurotransmitter acetylcholine, which causes symptoms similar to organophosphate or carbamate insecticides [160]. Extracts of tobacco leaves were mixed with bio-oil and high repellent activity was observed against Ae. aegypti [181]. Furthermore, nicotine has been found to be the most dominant compound among the other active compounds of the repellent mixture, including nicotine, d-limonene, indole, and pyridine. In addition, the repellent compound was harmless to human skin as confirmed by sensitivity tests on volunteers.

\subsection{Other Plant Compounds}

Besides the most common plant-based bioinsecticides mentioned above, there are other natural plant metabolites that show insecticidal properties. Among them, flavonoids elicit larvicidal activity by inhibiting AChE in mosquito larvae [182]. They could also act as respiratory inhibitors and result in the disturbance of the larval respiratory system. Alkaloids have multiple effects including inhibition of the AChE enzyme, degradation 
of cell membranes, and they may act as stomach poisons [182]. It has been shown that flavonoid and alkaloid components of bangle rhizome extract from Zingiber montanum act differently against Ae. aegypti [183]. Flavonoids from Derris trifoliata extract also exhibited larvicidal activity against Ae. aegypti [184]. Rotenone is an isoflavonoid extracted from roots and stems of Derris (Derris elliptica, Derris involute), Lonchocarpus (Lonchocarpus utilis, Lonchocarpus urucu) and Tephrosia virginiana [160]. It has long been used as a biopesticide due to less harmful effects to the environment. Rotenone has the potential to be used as a larvicide to control mosquitoes and interferes with the cellular respiration system of insects and prevents energy production [185].

\section{Assessment of Plant-Based Bioinsecticide Efficacy in Mosquito Control}

It is important that inherent activity of candidate bioinsecticides should be assessed before they can be effectively used against mosquito populations. The World Health Organization has established methods to screen the efficacy and field application acceptability of new compounds as potential mosquito larvicides and adulticides (for IRS and ITNs); they are laboratory studies, small-scale and large-scale field trials [186-188]. Laboratory studies focus on determination of biopotency, efficacy, residual activity, irritant or repellent properties, diagnostic concentration, and possible cross-resistance of candidate larvicides or adulticides. In laboratory bioassays, mosquito larvae are exposed to various concentrations of larvicides, and a mortality rate based on lethal concentration (LC) of the larvicide for $50 \%$ and $90 \%$ mortality (LC50 and LC90) or for 50\% and 90\% inhibition of adult emergence (IE50 and IE90) is recorded. LC values are determined and can then be compared with the LC50 or LC90 values of other insecticides to assess the activity of the compound as "sufficiently effective". For adulticides, LC is determined by tarsal contact to treated papers. The "time to first take-off" (FT) for the 50\% and 90\% of the mosquitoes to take off (FT50 and FT90) after exposure to treated substrates are measured to determine the irritant or repellent activity of an adulticide. Insecticide-treated nets are used for bioassays of adult mosquitoes to determine the efficacy and residual activity of different dosages of the candidate compounds. Moreover, efficacy and wash-resistance of ITNs against susceptible mosquito species should be determined using standard WHO cone bioassays or tunnel tests [188]. The efficacy criteria for cone bioassays are $\geq 80 \%$ mortality or $\geq 95 \%$ knock-down, and for the tunnel test, it is $\geq 80 \%$ mortality or $\geq 90 \%$ blood-feeding inhibition. Candidate larvicides and adulticides are also tested against multi-resistant mosquito strains and a susceptible reference strain to assess the cross-resistance and, if detected, biochemical, immunological, and molecular methods are used to determine the mechanism of resistance [189].

Once candidate compounds are selected from laboratory tests, they are subjected to small-scale field testing in natural breeding sites (such as drains sewage water tanks, ponds, rice plots, etc.) or under simulated field conditions (artificial containers filled with water, experimental huts). Larvicidal efficacy is determined by the level of inhibition of emergence of adults and the percentage reduction in larval and pupal densities, while adulticidal efficacy can be assessed in terms of mortality, residual effect, deterrence, blood-feeding inhibition and induced exophily. These trials elucidate efficacy of candidate compounds against different mosquito species in different breeding sites, determine optimum field application dosage of the compound and possible impact on the mosquito behavior. Abiotic parameters that may influence the efficacy of the product and effect on non-target organisms can also be observed. Those larvicides and adulticides that show promise in small-scale field trials should be validated in larger-scale field trials against natural mosquito populations in natural breeding habitats using optimum field dosages. At this stage, the storage, handling, and application of the insecticide formulation should be considered for proper functioning of application and dispersal of the bioinsecticide in natural ecosystems.

There are also potential limitations to the efficacy of bioinsecticides, such as environmental conditions, mosquito fitness, mosquito resistance as well as the parts of the plants used, solvents used in extraction steps, insecticide dose and exposure time [190,191]. These effects should be considered for successful assessment of novel bioinsecticides in mosquito 
control. While efficacy tests provide promising information on possible mosquitocidal effects, new compounds from plant origin, the identification of actual active ingredient for efficacy and their mode of action are still waiting to be resolved.

\section{Effective Use of Plant-Based Bioinsecticides in Resistant Mosquito Populations}

Most of the bioinsecticides are now effective alternatives to chemical insecticides and have become an integral part of the integrated mosquito management (IMM) programs because the development of resistance to bioinsecticides is low due to their multiple mode of actions [192,193]. The synergic mixture of the active compounds in plant extracts also minimizes resistance development [167]. However, resistance already developed to extensively used chemical insecticides is a major problem that limits the success rate of novel bioinsecticides against mosquito populations. Insecticide resistance should be reduced or reverted (which takes time) in order to apply new and effective bioinsecticides in resistant populations. Surveillance of mosquito resistance and effective resistance management strategies should be routinely conducted to determine the levels, mechanisms, and geographic distribution of resistance in field populations of mosquitoes for increasing efficacy of bioinsecticides [44]. Moreover, proper application technologies should be considered as they greatly influence the bioinsecticide efficacy.

Surveillance of resistance development to many different insecticides are determined by dose-mortality bioassays, the World Health Organization tube testing, and Centers for Disease Control and Prevention (CDC) bottle bioassay for mosquitoes [11,44,194,195]. In the dose-mortality assay, the resistance ratio (RR) is determined in a susceptible population to monitor changes in resistance over time. The RR is calculated from LC50 values of the field and susceptible populations, in which an RR lower than five indicates susceptibility or low resistance and an RR value higher than ten indicates high resistance. In the WHO tube testing, the insecticide susceptibility status of the selected mosquitoes is evaluated through susceptibility tests measuring the mortality rate twenty-four hour after exposure [44]. A mortality rate lower than $98 \%$ indicates occurrence of resistance and should be confirmed with biochemical and molecular analysis. A mortality rate less than $90 \%$ confirms the existence of resistant genes in the tested mosquito populations. The CDC bottle bioassay is a measure of insecticide effectiveness, where diagnostic doses (DDs) and diagnostic times (DTs) are determined for candidate compounds using susceptible mosquitoes prior to testing in field mosquito populations. The DD is a measure of insecticide dose that kills $100 \%$ of susceptible mosquitoes within a certain period of time (DT). A mortality rate lower than $97 \%$ is an indication of resistance that needs to be confirmed, and below $80 \%$ suggests strong resistance at the recommended DT. The DD and DT values for some active ingredients are available for Anopheles and Aedes mosquito populations and these parameters should be defined for a particular insecticide and mosquito population [195].

It is evident that no single strategy is effective enough to solve insecticide resistance of mosquitoes. According to the WHO [44], one strategy to prevent the resistance problem is rotational usage of different classes of bioinsecticides with different modes of action. There are several new plant-based larvicides with different modes of action (discussed in Section 5) and they could be good alternatives for mosquito control in larval stages. Additionally, multiple interventions that affect different stages of mosquitoes (such as larvae and adults) can be used together to manage insecticide resistance. It is also suggested that different classes of insecticides with different modes of action can be used in neighboring geographic locations. To successfully implement these strategies, knowledge of the mode of action of the novel bioinsecticide is essential. The resistance mechanism developed by the local population of mosquitoes should also be determined to reduce cross-resistance effects.

RNA interference (RNAi) mediated loss-of-function technique has been proposed for pest management programs $[196,197]$ and to study insecticide resistance [198]. Genes responsible for resistance development in insects (e.g., genes for DDT or pyrethroid resistance) can be identified and used as a target for the development of novel RNAi based insecticides. Several delivery methods including nonmicrobial and microbial are used 
routinely to induce RNAi in mosquito larvae [199]. Nonmicrobial delivery methods consist of soaking, injection, nanoparticles and dehydration and rehydration. Although soaking and injection methods are used as excellent tools in RNAi research, they have no application in the field. Soaking, injection methods and nanoparticles have been effectively used to introduce dsRNA into first-instar Ae. aegypti larvae [200] and fourth instars of Ae. aegypti [201]. In mosquitoes, a chitosan/dsRNA-based nanoparticle has also been used in feeding the larvae of An. gambiae mosquitoes which led to successful gene silencing of two chitin synthase genes and increased susceptibilities to DTT [202]. Such an RNAi-based bioinsecticide can be potentially used as an effective strategy to enhance the efficacy of new bioinsecticides for mosquito control.

Another technology used for the manipulation of insect behavior is "Specialized Pheromone and Lure Application Technology (SPLAT)". SPLAT is a chemical controlledrelease emulsion technology, and it has been used as an alternative management strategy to target the aquatic life stages of mosquitoes [203]. SPLAT emulsions can be formulated by using a variety of compounds, such as sex pheromones, attractants, repellents, phagostimulants and insecticides. SPLAT consists of both aqueous and non-aqueous components. The aqueous component of the SPLAT emulsion is involved in the liquid property of the product and evaporates within $3 \mathrm{~h}$ upon application. The non-aqueous component of the emulsion is the controlled-release device that releases active ingredients (e.g., semiochemical or pesticides) at a controlled rate for 2 weeks to 6 months by protecting the active ingredients from environmental, chemical, and biological degradation. It has been reported that combination of attractant and larvicidal agents in a single formulation and biodegradable matrices causes significant increase in larval mosquito mortality, specifically $C x$. quinquefasciatus, compared to formulations consisting of larvicidal agents alone in semi-field trials (e.g., large-screened greenhouse and emulating field conditions) [204]. The major benefits of this technology are a timely-manner release of both pheromone and insecticide, reduced insecticide resistance, and persistence in the field [203].

\section{How to Improve Plant-Based Bioinsecticide Efficacy in Mosquito Control Strategies?}

Synthetic chemicals used to control mosquitoes are now causing serious health problems and, more importantly, resistant mosquitoes that lead to search for more effective, healthier, safer, and eco-friendly natural solutions. Phytochemicals derived from plant resources are excellent targets to search for bioactive compounds because plants synthesize these chemicals naturally in response to their environment (such as against insect predators and microbial attacks), thus, plants are indeed natural insecticide sources. While searching the literature for plant-based compounds, we have encountered a tremendous number of efforts to identify and evaluate compounds that could have potential mosquitocidal activity with negative impact on mosquito physiology at different development stages. Since phytochemicals have multiple modes of action and exert their effects on multiple target sites in insects, their efficacy can be enhanced when used as a blend (e.g., mixture of oils) against mosquitoes. In addition, insects are more likely to develop resistance to a single chemical compound rather than a mixture of compounds. Thus, a combinatorial usage of phytochemicals would limit development of resistance in mosquitoes. Phytochemicals have short residual half-life which could be advantageous when synergistically used together with other biological control agents [205]. It is encouraging that these features of phytochemicals make them alternative natural solutions for the development of suitable products to interfere with the mosquito-host interaction and reduce disease transmission.

Among the phytochemicals, essential oils are extensively studied and their repellent activities against mosquitoes makes them favorable natural chemicals. However, they are volatile compounds, and this causes issues in their long-term applications in mosquito control. In recent years, new technologies, such as microencapsulation and nanoemulsion, have been used to overcome this problem by enhancing the duration and efficacy of essential oils [140]. Since ITNs are one of the major intervention methods to control 
mosquitoes, the incorporation of plant-based insect repellents in fabrics seems a prompt and alternative way to provide safer protection against mosquito bites. Fabrics treated with microencapsulated citronella essential oil have been reported to provide higher repellent activity and longer lasting protection, up to three weeks, against insects compared to the fabrics sprayed with ethanol solution of the essential oil [206]. Grancaric et al. [207] also reported that microencapsulated immortelle oil had the highest repellent efficacy against Ae. aegypti compared to immortelle oil alone on cotton samples. In another study, microcapsules composed of two biopesticides, namely citronella essential oil and citriodiol, were prepared and applied to cotton textiles using a variety of techniques. As a result, citriodiol-treated cotton fabrics had a prolonged durability, and 100\% repellent activity for more than 30 days after its application [208]. Additionally, encapsulation of citronella oil into microcapsules of poly $\varepsilon$-caprolactone has been considered as an effective and sustained release system with potential application in protection against mosquitoes [209]. Encapsulated citronella oil nanoemulsions prepared by high pressure homogenization at varying amounts of surfactant and glycerol were tested for mosquito repellency. It has been shown that increasing concentration of glycerol and surfactant improved the stability of the emulsion causing prolonged mosquito protection [210]. These results clearly indicate that through microencapsulation and nanoemulsion formulation technologies, effective and longer usage of essential oils on cotton fabrics or ITNs can be achieved.

Neem-based insecticides can also be effectively used for the control of mosquitoes. They are considered more eco-friendly than synthetic insecticides and are less prone to induce resistance because of their multiple modes of action on insects. Another advantage of neem oil formulations is that it causes mortality at relatively low concentrations making them potential alternatives to synthetic insecticides in the control of malaria vectors. Microencapsulation of neem seed oil and karanja oil has been used for the control of larvae of Ae. aegypti [211]. The major drawback of using neem oil is that its dosage should be considered when applied in the field because neem can cause risks to non-target organisms at higher doses.

Natural pyrethrins are now considered as a potential alternative to synthetic DTT and can overcome hazardous effects of pyrethroids. However, they have major drawbacks which include their high instability and quick degradation in the presence of sunlight. Stability concerns and short duration of their knockdown effect cause inadequate field applications against mosquito populations during the day [212]. However, the application of pyrethrin-based insecticides after sunset against Culex and Anopheles has shown a decrease in mosquito populations and protection against non-target insects [213]. Pyrethrins are also more effective when used with a synergist. They can be easily degraded before having an impact on mosquitoes, thus should be applied with a synergist of non-synthetic origin. Since pyrethrin-based chemicals are detected via mosquito olfactory organs and processed through olfactory signal transduction mechanisms, pyrethrin-based repellent molecules should be developed and implemented in order to interfere with the host-seeking behavior of mosquitoes for an effective reduction in disease transmission.

Despite our increasing knowledge on plant-based bioactive compounds and their multiple mode of actions on insects, a few of them, such as essential oil-based and neem-based insecticides, have been commercially available for pest management [205]. One of the reasons that causes their limited usage in the field is the formulation problem to overcome phytotoxic effects. The chemical composition of each compound should be formulated in such a way that it should be bioactive to target insects and non-toxic to non-target organisms. In addition, formulation of plant-based bioinsecticides should ensure that it can be produced in large quantities through biomass production of plants and administered in recommended dosages to minimize toxic effects, and biological activity can be maintained for longer shelf-life. As discussed above, microencapsulation and nanoemulsion technologies have benefits in solving formulation issues of phytochemicals. A new formulation in the form of tablets containing a lectin preparation showed mosquitocidal activity against different developmental stages of Ae. aegypti mosquitoes, and this formulation method 
is proposed as a new control strategy for Ae. aegypti populations [214]. Phytochemicals break down rapidly and this causes a need for continuous and more frequent applications in the field for a satisfactory impact on mosquito control. Further studies are needed with the implementation of new methods for the development of effective bioinsecticides from other plant-based bioactive compounds.

\section{Conclusions}

Mosquitoes are important vectors of devastating diseases, and their hazardous effects are far beyond eradication. The occurrence/reoccurrence of mosquitoes in endemic, nonendemic, and new regions of the world has led to extensive use of synthetic chemicals to control transmission of mosquito-borne diseases. With the increase of resistant mosquitoes and toxicity issues to target and non-target organisms, safer, biodegradable, target-specific alternatives have been considered to replace conventional mosquito control strategies. Phytochemicals have gained importance to overcome mosquito control problems as being considered natural, environmentally safe, less toxic, inexpensive, and, more importantly, less prone to mosquito resistance. Variety of plant extracts have been reported to have mosquitocidal or repellent activity against mosquito vectors, mostly depending on laboratory assays, but there are limitations for their efficacy and applicability in the field. Problems associated with their formulation and commercialization, non-standardization in evaluation of their bioactivities, and their persistence for longer durations should be resolved for development of effective and sustainable methods for their usage. There is no doubt that there are more bioactive compounds that require exploring, and future research should focus on searching for plant-based products with the ultimate goal of deploying them as a reliable remedy to control mosquito populations and mosquito-borne diseases.

Author Contributions: Conceptualization, M.Ş.Ş.D.; original draft preparation, M.Ş.Ş.D. and E.C.; review and editing, M.Ş.Ş.D. and E.C. All authors have read and agreed to the published version of the manuscript.

Funding: This research received no external funding.

Institutional Review Board Statement: Not applicable.

Data Availability Statement: Not applicable.

Acknowledgments: The authors thank the editorial board of Insects and the reviewers for comments and suggestions.

Conflicts of Interest: The authors declare no conflict of interest.

\section{References}

1. Kilpatrick, A.M. Globalization, land use and the invasion of West Nile virus NIH Public Access. Science 2011, 334, 323-327. [CrossRef] [PubMed]

2. WHO. World Malaria Report 2020: 20 Years of Global Progress and Challenges; World Health Organization: Geneva, Switzerland, 2020.

3. Du, M.; Jing, W.; Liu, M.; Liu, J. The Global Trends and Regional Differences in Incidence of Dengue Infection from 1990 to 2019 : An Analysis from the Global Burden of Disease Study 2019. Infect. Dis. Ther. 2021, 10, 1625-1643. [CrossRef] [PubMed]

4. $\quad$ Bhatt, S.; Gething, P.W.; Brady, O.J.; Messina, J.P.; Farlow, A.W.; Moyes, C.L.; Drake, J.M.; Brownstein, J.S.; Hoen, A.G.; Sankoh, O.; et al. The global distribution and burden of dengue. Nature 2013, 496, 504-507. [CrossRef] [PubMed]

5. Stanaway, J.D.; Shepard, D.S.; Undurraga, E.A.; Halasa, Y.A.; Coffeng, L.E.; Brady, O.J.; Hay, S.I.; Bedi, N.; Bensenor, I.M.; Castañeda-Orjuela, C.A.; et al. The global burden of dengue: An analysis from the Global Burden of Disease Study 2013. Lancet Infect. Dis. 2016, 16, 712-723. [CrossRef]

6. Paixão, E.S.; Teixeira, M.G.; Rodrigues, L.C. Zika, chikungunya and dengue: The causes and threats of new and re-emerging arboviral diseases. BMJ Glob. Health 2018, 3, e000530. [CrossRef]

7. Kraemer, M.U.G.; Reiner, R.C.; Brady, O.J.; Messina, J.P.; Gilbert, M.; Pigott, D.M.; Yi, D.; Johnson, K.; Earl, L.; Marczak, L.B.; et al. Past and future spread of the arbovirus vectors Aedes aegypti and Aedes albopictus. Nat. Microbiol. 2019, 4, 854-863. [CrossRef]

8. Altizer, S.; Ostfeld, R.S.; Johnson, P.T.J.; Kutz, S.; Harvell, C.D. Climate change and infectious diseases: From evidence to a predictive framework. Science 2013, 341, 514-519. [CrossRef]

9. Mordecai, E.A.; Ryan, S.J.; Caldwell, J.M.; Shah, M.M.; LaBeaud, A.D. Climate change could shift disease burden from malaria to arboviruses in Africa. Lancet Planet Health 2020, 4, e416-e423. [CrossRef] 
10. WHO. Global Report on Insecticide Resistance in Malaria Vectors: 2010-2016; World Health Organization: Geneva, Switzerland, 2018.

11. Richards, S.L.; Byrd, B.D.; Reiskind, M.H.; White, A.V. Assessing Insecticide Resistance in Adult Mosquitoes: Perspectives on Current Methods. Environ. Health Insights 2020, 14, 1-7. [CrossRef]

12. Lines, J.D.; Myamba, J.; Curtis, C.F. Experimental hut trials of permethrin-impregnated mosquito nets and eave curtains against malaria vectors in Tanzania. Med. Vet. Entomol. 1987, 1, 37-51. [CrossRef]

13. Lindsay, S.W.; Adiamah, J.H.; Miller, J.E.; Armstrong, J.R.M. Pyrethroid-treated bednet effects on mosquitoes of the Anopheles gambiae complex in The Gambia. Med. Vet. Entomol. 1991, 5, 477-483. [CrossRef] [PubMed]

14. Miller, J.E.; Lindsay, S.W.; Armstrong, J.R. Experimental hut trials of bednets impregnated with synthetic pyrethroid or organophosphate insecticide for mosquito control in The Gambia. Med. Vet. Entomol. 1991, 5, 465-476. [CrossRef]

15. Gimnig, J.E.; Vulule, J.M.; Lo, T.Q.; Kamau, L.; Kolczak, M.S.; Phillips-Howard, P.A.; Mathenge, E.M.; Ter Kuile, F.O.; Nahlen, B.L.; Hightower, A.W. Impact of permethrin-treated bed nets on the entomologic indices in an area of intense year-round malaria transmission. Am. J. Trop. Med. Hyg. 2003, 68, 16-22. [CrossRef]

16. Lengeler, C. Insecticide-treated bed nets and curtains for preventing malaria. Cochrane Database Syst. Rev. 2004, 2, CD000363. [CrossRef]

17. Killeen, G.F. Characterizing, controlling and eliminating residual malaria transmission. Malar. J. 2014, 13, 330. [CrossRef]

18. Killeen, G.F.; Smith, T.A.; Ferguson, H.M.; Mshinda, H.; Abdulla, S.; Lengeler, C.; Kachur, S.P. Preventing Childhood Malaria in Africa by Protecting Adults from Mosquitoes with Insecticide-Treated Nets. PLoS Med. 2007, 4, e229. [CrossRef]

19. Pluess, B.; Tanser, F.C.; Lengeler, C.; Sharp, B.L. Indoor residual spraying for preventing malaria. Cochrane Database Syst. Rev. 2010, 4, CD006657. [CrossRef] [PubMed]

20. Bhatt, S.; Weiss, D.J.; Cameron, E.; Bisanzio, D.; Mappin, B.; Dalrymple, U.; Battle, K.; Moyes, C.L.; Henry, A.; Eckhoff, P.A.; et al. The effect of malaria control on Plasmodium falciparum in Africa between 2000 and 2015. Nature 2015, 526, 207-211. [CrossRef] [PubMed]

21. Cibulskis, R.E.; Alonso, P.; Aponte, J.; Aregawi, M.; Barrette, A.; Bergeron, L.; Fergus, C.A.; Knox, T.; Lynch, M.; Patouillard, E.; et al. Malaria: Global progress 2000-2015 and future challenges. Infect. Dis. Poverty 2016, 5, 61. [CrossRef] [PubMed]

22. Soderlund, D.M.; Bloomquist, J.R. Neurotoxic actions of pyrethroid insecticides. Annu. Rev. Entomol. 1989, 34, 77-96. [CrossRef]

23. Lund, A.E.; Narahashi, T. Kinetics of sodium channel modification as the basis for the variation in the nerve membrane effects of pyrethroids and DDT analogs. Pest Biochem. Physiol. 1983, 20, 203-216. [CrossRef]

24. Soderlund, D.M. Mode of action of pyrethrins and pyrethroids. In Pyrethrum Flowers: Production, Chemistry, Toxicology, and Uses; Casida, J.E., Quistad, G.B., Eds.; Oxford University Press: New York, NY, USA, 1995; pp. 217-233.

25. Narahashi, T. Neuronal ion channels as the target sites of insecticides. Pharmacol. Toxicol. 1996, 78, 1-14. [CrossRef] [PubMed]

26. Bowman, N.M.; Akialis, K.; Cave, G.; Barrera, R.; Apperson, C.S.; Meshnick, S.R. Pyrethroid insecticides maintain repellent effect on knock-down resistant populations of Aedes aegypti mosquitoes. PLoS ONE 2018, 13, e0196410. [CrossRef]

27. Ranson, H.; Jensen, B.; Vulule, J.M.; Wang, X.; Hemingway, J.; Collins, F.H. Identification of a point mutation in the voltage-gated sodium channel gene of Kenyan Anopheles gambiae associated with resistance to DDT and pyrethroids. Insect Mol. Biol. 2000, 9 , 491-497. [CrossRef]

28. Etang, J.; Chandre, F.; Guillet, P.; Manga, L. Reduced bio-efficacy of permethrin EC impregnated bednets against an Anopheles gambiae strain with oxidase-based pyrethroid tolerance. Malar. J. 2004, 3, 46. [CrossRef]

29. Yang, G.G.; Kim, D.; Pham, A.; Paul, C.J. A meta-regression analysis of the effectiveness of mosquito nets for malaria control: The value of long-lasting insecticide nets. Int. J. Environ. Res. Public Health 2018, 15, 546. [CrossRef] [PubMed]

30. Eskenazi, B.; Chevrier, J.; Rosas, L.G.; Anderson, H.A.; Bornman, M.S.; Bouwman, H.; Chen, A.; Cohn, B.A.; de Jager, C.; Henshel, D.S.; et al. The Pine River Statement: Human health consequences of DDT use. Environ. Health Perspect. 2009, 117, $1359-1367$. [CrossRef] [PubMed]

31. Bouwman, H.; van den Berg, H.; Kylin, H. DDT and malaria prevention: Addressing the paradox. Environ. Health Perspect. 2011, 119, 744-747. [CrossRef]

32. Hosie, A.M.; Aronstein, K.; Sattelle, D.B.; ffrench-Constant, R.H. Molecular biology of insect neuronal GABA receptors. Trends Neurosci. 1997, 20, 578-583. [CrossRef]

33. Lawrence, L.J.; Casida, J.E. Stereospecifc action of pyrethroid insecticides on the gamma-aminobutyric acid receptor-ionophore complex. Science 1983, 221, 1399-1401. [CrossRef] [PubMed]

34. Bloomquist, J.R. Toxicology, mode of action and target site-mediated resistance to insecticides acting on chloride channels. Comp. Biochem. Physiol. Part C Pharmacol. Toxicol. Endocrinol. 1993, 106, 301-314. [CrossRef]

35. Buckingham, S.D.; Ihara, M.; Sattelle, D.B.; Matsuda, K. Mechanisms of Action, Resistance and Toxicity of Insecticides Targeting GABA Receptors. Curr. Med. Chem. 2017, 24, 2935-2945. [CrossRef]

36. Mengle, D.C.; Casida, J.E. Inhibition and recovery of brain cholinesterase activity in house flies poisoned with organophosphate and carbamate compounds. J. Econ. Entomol. 1958, 51, 750-757. [CrossRef]

37. Fukuto, T.R. Mechanism of action of organophosphorus and carbamate insecticides. Environ. Health Perspect. 1990, 87, 245-254. [CrossRef]

38. Fournier, D.; Mutero, A. Modification of acetylcholinesterase as a mechanism of resistance to insecticides. Comp. Biochem. Physiol. Part C Pharmacol. Toxicol. Endocrinol. 1994, 108, 19-31. [CrossRef]

39. Smith, G. Kern MAD has circumstantial evidence on DDT resistance. Mosquito Buzz 1949, 3, 2. 
40. Gjullin, C.M.; Peters, R.F. Recent studies of mosquito resistance to insecticides in California. Mosq. News 1952, $12,1-7$.

41. Akogbeto, M.; Yakoubou, S. Resistance of malaria vectors to pyrethroids used for impregnated mosquito nets in Benin, West Africa. Bull. Soc. Path. Exot. 1999, 92, 123-130.

42. Ranson, H.; N'Guessan, R.; Lines, J.; Moiroux, N.; Nkuni, Z.; Corbel, V. Pyrethroid resistance in African anopheline mosquitoes: What are the implications for malaria control? Trends Parasitol. 2011, 27, 91-98. [CrossRef]

43. Deletre, E.; Martin, T.; Duménil, C.; Chandre, F. Insecticide resistance modifies mosquito response to DEET and natural repellents. Parasites Vectors 2019, 12, 89. [CrossRef]

44. WHO. Test Procedures for Insecticide Resistance Monitoring in Malaria Vector Mosquitoes, 2nd ed.; World Health Organization: Geneva, Switzerland, 2016.

45. Rozendaal, J.A. House-spraying with residual insecticides. In Vector Control-Methods for Use by Individuals and Communities; World Health Organization: Geneva, Switzerland, 1997; pp. 357-384.

46. Hemingway, J.; Ranson, H. Insecticide resistance in insect vectors of human disease. Annu. Rev. Entomol. 2000, 45, 371-391. [CrossRef] [PubMed]

47. WHO. Global Plan for Insecticide Resistance Management in Malaria Vectors; World Health Organization: Geneva, Switzerland, 2012.

48. Liu, N. Insecticide resistance in mosquitoes: Impact, mechanisms, and research directions. Annu. Rev. Entomol. 2015, 60, 537-559. [CrossRef]

49. Andreazza, F.; Oliveira, E.E.; Martins, G.F. Implications of Sublethal Insecticide Exposure and the Development of Resistance on Mosquito Physiology, Behavior, and Pathogen Transmission. Insects 2021, 12, 917. [CrossRef] [PubMed]

50. Martinez-Torres, D.; Chandre, F.; Williamson, M.S.; Darriet, F.; Berge, J.B.; Devonshire, A.L.; Guillet, P.; Pasteur, N.; Pauron, D. Molecular characterization of pyrethroid knockdown resistance $(k d r)$ in the major malaria vector Anopheles gambiae s.s. Insect Mol. Biol. 1998, 7, 179-184. [CrossRef]

51. Dong, K. Insect sodium channels and insecticide resistance. Invert. Neurosci. 2007, 7, 17-30. [CrossRef] [PubMed]

52. Oliveira, E.E.; Du, Y.; Nomura, Y.; Dong, K. A residue in the transmembrane segment 6 of domain I in insect and mammalian sodium channels regulate differential sensitivities to pyrethroid insecticides. Neurotoxicology 2013, 38, 42-50. [CrossRef]

53. Rinkevich, F.D.; Du, Y.; Dong, K. Diversity and convergence of sodium channel mutations involved in resistance to pyrethroids. Pestic. Biochem. Physiol. 2013, 106, 93-100. [CrossRef]

54. Dong, K.; Du, Y.; Rinkevich, F.; Nomura, Y.; Xu, P.; Wang, L.; Silver, K.; Zhorov, B.S. Molecular biology of insect sodium channels and pyrethroid resistance. Insect Biochem. Mol. Biol. 2014, 50, 1-17. [CrossRef]

55. Silver, K.S.; Du, Y.; Nomura, Y.; Oliveira, E.E.; Salgado, V.L.; Zhorov, B.S.; Dong, K. Voltage-gated sodium channels as insecticide targets. Adv. Insect Phys. 2014, 46, 389-433.

56. Pauron, D.; Barhanin, J.; Amichot, M.; Pralavorio, M.; Berge, J.B.; Lazdunski, M. Pyrethroid receptor in the insect Na+ channel: Alteration of its properties in pyrethroid-resistant flies. Biochem J. 1989, 28, 1673-1677. [CrossRef]

57. Soderlund, D.M.; Knipple, D.C. The molecular biology of knockdown resistance to pyrethroid insecticides. Insect Biochem. Mol. Biol. 2003, 33, 563-577. [CrossRef]

58. Chandre, F.; Darriet, F.; Duchon, S.; Finot, L.; Manguin, S.; Carnevale, P.; Guillet, P. Modifications of pyrethroid effects associated with $k d r$ mutation in Anopheles gambiae. Med. Vet. Entomol. 2000, 14, 81-88. [CrossRef]

59. Gan, S.J.; Leong, Y.Q.; bin Barhanuddin, M.F.H.; Wong, S.T.; Wong, S.F.; Mak, J.W.; Ahmad, R.B. Dengue fever and insecticide resistance in Aedes mosquitoes in Southeast Asia: A review. Parasites Vectors 2021, 14, 1-19. [CrossRef] [PubMed]

60. Weill, M.; Fort, P.; Berthomieu, A.; Dubois, M.P.; Pasteur, N.; Raymond, M. A novel acetyl-cholinesterase gene in mosquitoes codes for the insecticide target and is non-homologous to the ace gene in Drosophila. Proc. Biol. Sci. 2002, 269, 2007-2016. [CrossRef] [PubMed]

61. Weill, M.; Lutfalla, G.; Mogensen, K.; Chandre, F.; Berthomieu, A.; Berticat, C.; Pasteur, N.; Philips, A.; Fort, P.; Raymond, M. Comparative genomics: Insecticide resistance in mosquito vectors. Nature 2003, 423, 136-137. [CrossRef] [PubMed]

62. Alout, H.; Djogbénou, L.; Berticat, C.; Chandre, F.; Weill, M. Comparison of Anopheles gambiae and Culex pipiens acetylcholinesterase 1 biochemical properties. Comp. Biochem. Physiol. B Biochem. Mol. Biol. 2008, 150, 271-277. [CrossRef] [PubMed]

63. Djogbénou, L.; Akogbeto, M.; Chandre, F. Presence of insensitive acetylcholinesterase in wild populations of Culex pipiens quinquefasciatus from Benin. Acta Trop. 2008, 107, 272-274. [CrossRef] [PubMed]

64. Cole, L.M.; Roush, T.T.; Casida, J.E. Drosophila GABA-gated chloride channel: Modified [3H]EBOB binding site associated with $\mathrm{Ala} \rightarrow$ Ser or Gly mutants of Rdl subunit. Life Sci. 1995, 56, 757-765. [CrossRef]

65. Du, W.; Awolola, T.S.; Howell, P.; Koekemoer, L.L.; Brooke, B.D. Independent mutations in the Rdl locus confer dieldrin resistance to Anopheles gambiae and An. arabiensis. Insect Mol. Biol. 2005, 14, 179-183. [CrossRef]

66. Wondji, C.S.; Dabire, R.K.; Tukur, Z.; Irving, H.; Djouaka, R.; Morgan, J.C. Identification and distribution of a GABA receptor mutation conferring dieldrin resistance in the malaria vector Anopheles funestus in Africa. Insect Biochem. Mol. Biol. 2011, 41, 484-491. [CrossRef]

67. Taylor-Wells, J.; Brooke, B.D.; Bermudez, I.; Jones, A.K. The neonicotinoid imidacloprid, and the pyrethroid deltamethrin, are antagonists of the insect $R d l$ GABA receptor. J. Neurochem. 2015, 135, 705-713. [CrossRef] [PubMed]

68. Marcombe, S.; Thammavong, P.; Luangamath, P.; Chonephetsarath, S.; Phommavanh, N.; Lakeomany, K.; Nilaxay, S.; Rahmani, Z.; Saverton, P.J.; Abdullateef, O.H. Malaria and Dengue Mosquito Vectors from Lao PDR Show a Lack of the $r d l$ Mutant Allele Responsible for Cyclodiene Insecticide Resistance. J. Med. Entomol. 2020, 57, 815-823. [CrossRef] 
69. Amelia-Yap, Z.H.; Tan, T.K.; Prakash, B.K.; Chen, C.D.; Sofian-Azirun, M.; Low, V.L. First report of Rdl mutant alleles in Culex quinquefasciatus (Diptera: Culicidae) in Malaysia. J. Vector Borne Dis. 2020, 57, 359-361. [PubMed]

70. Kasai, S.; Weerasinghe, I.S.; Shono, T. P450 Monooxygenases are an important mechanism of permethrin resistance in Culex quinquefasciatus say larvae. Arch. Insect Biochem. Physiol. 1998, 37, 47-56. [CrossRef]

71. Brogdon, W.G.; McAllister, J.C.; Corwin, A.M.; Cordon-Rosales, C. Independent selection of multiple mechanisms for pyrethroid resistance in Guatemalan Anopheles albimanus (Diptera:Culicidae). J. Econ. Entomol. 1999, 92, 298-302. [CrossRef]

72. Vulule, J.M.; Beach, R.F.; Atieli, F.K.; McAllister, J.C.; Brogdon, W.G.; Roberts, J.M.; Mwangi, R.W.; Hawley, W.A. Elevated oxidase and esterase levels associated with permethrin tolerance in Anopheles gambiae from Kenyan villages using permethrin-impregnated nets. Med. Vet. Entomol. 1999, 13, 239-244. [CrossRef] [PubMed]

73. Wondji, C.S.; Irving, H.; Morgan, J.; Lobo, N.F.; Collins, F.H.; Hunt, R.H.; Coetzee, M.; Hemingway, J.; Ranson, H. Two duplicated P450 genes are associated with pyrethroid resistance in Anopheles funestus, a major malaria vector. Genome Res. 2009, 19, 452-459. [CrossRef] [PubMed]

74. Wondji, C.S.; Coleman, M.; Kleinschmidt, I.; Mzilahowa, T.; Irving, H.; Ndula, M. Impact of pyrethroid resistance on operational malaria control in Malawi. Proc. Natl. Acad. Sci. USA 2012, 109, 19063-19070. [CrossRef]

75. David, J.-P.; Ismail, H.M.; Chandor-Proust, A.; Paine, M.J.I. Role of cytochrome P450s in insecticide resistance: Impact on the control of mosquito-borne diseases and use of insecticides on Earth. Phil. Trans. R. Soc. B 2013, 368, 20120429. [CrossRef]

76. Vontas, J.; Katsavou, E.; Mavridis, K. Cytochrome P450-based metabolic insecticide resistance in Anopheles and Aedes mosquito vectors: Muddying the waters. Pestic. Biochem. Physiol. 2020, 170, 104666. [CrossRef]

77. Yang, T.; Li, T.; Feng, X.; Li, M.; Liu, S.; Liu, N. Multiple cytochrome P450 genes: Conferring high levels of permethrin resistance in mosquitoes, Culex quinquefasciatus. Sci. Rep. 2021, 11, 9041. [CrossRef] [PubMed]

78. Lycett, G.J.; McLaughlin, L.A.; Ranson, H.; Hemingway, J.; Kafatos, F.C.; Loukeris, T.G.; Paine, M.J.I. Anopheles gambiae P450 reductase is highly expressed in oenocytes and in vivo knockdown increases permethrin susceptibility. Insect Mol. Biol. 2006, 15, 321-327. [CrossRef]

79. Li, T.; Cao, C.; Yang, T.; Zhang, L.; He, L.; Xi, Z.; Bian, G.; Liu, N. A G-protein-coupled receptor regulation pathway in cytochrome P450-mediated permethrin-resistance in mosquitoes, Culex quinquefasciatus. Sci. Rep. 2016, 5, 17772. [CrossRef] [PubMed]

80. Li, T.; Liu, N. Regulation of P450-mediated permethrin resistance in Culex quinquefasciatus by the GPCR/Gas/AC/cAMP/PKA signaling cascade. Biochem. Biophys. Rep. 2017, 12, 12-19.

81. Hemingway, J.; Hawkes, N.J.; McCarroll, L.; Ranson, H. The molecular basis of insecticide resistance in mosquitoes. Insect Biochem. Mol. Biol. 2004, 34, 653-665. [CrossRef] [PubMed]

82. Grant, D.F.; Matsumura, F. Glutathione S-transferase 1 and 2 in susceptible and insecticide resistant Aedes aegypti. Pestic. Biochem. Physiol. 1989, 33, 132-143. [CrossRef]

83. Prapanthadara, L.; Hemingway, J.; Ketterman, A.J. Partial purification and characterization of glutathione S-transferase involved in DDT resistance from the mosquito Anopheles gambiae. Pest. Biochem. Physiol. 1993, 47, 119-133. [CrossRef]

84. Ortelli, F.; Rossiter, L.C.; Vontas, J.; Ranson, H.; Hemingway, J. Heterologous expression of four glutathione transferase genes genetically linked to a major insecticide-resistance locus from the malaria vector Anopheles gambiae. Biochem. J. 2003, 373, 957-963. [CrossRef]

85. Ding, Y.; Ortelli, F.; Rossiter, L.C.; Hemingway, J.; Ranson, H. The Anopheles gambiae glutathione transferase supergene family: Annotation, phylogeny and expression profiles. BMC Genom. 2003, 4, 35. [CrossRef]

86. Lumjuan, N.; MaCarroll, L.; Prapanthadara, L.A.; Hemingway, J.; Ranson, H. Elevated activity of an Epsilon class glutathione S-transferase confers DDT resistance in the dengue vector, Aedes aegypti. Insect Biochem. Mol. Biol. 2005, 35, 861-871. [CrossRef]

87. Lumjuan, N.; Rajatileka, S.; Changsom, D.; Wicheer, J.; Leelapat, P.; Prapanthadara, L.; Somboon, P.; Lycett, G.; Ranson, H. The role of the Aedes aegypti Epsilon glutathione transferases in conferring resistance to DDT and pyrethroid insecticides. Insect Biochem. Mol. Biol. 2011, 41, 203-209. [CrossRef] [PubMed]

88. Marcombe, S.; Poupardin, R.; Darriet, F.; Reynaud, S.; Bonnet, J.; Strode, C.; Brengues, C.; Yebakima, A.; Ranson, H.; Corbel, V.; et al. Exploring the molecular basis of insecticide resistance in the dengue vector Aedes aegypti: A case study in Martinique Island (French West Indies). BMC Genom. 2009, 10, 494. [CrossRef] [PubMed]

89. Karunaratne, S.H.; Hemingway, J.; Jayawardena, K.G.; Dassanayaka, V.; Vaughan, A. Kinetic and molecular differences in the amplified and non-amplified esterases from insecticide-resistant and susceptible Culex quinquefasciatus mosquitoes. J. Biol. Chem. 1995, 270, 31124-31128. [CrossRef] [PubMed]

90. Ketterman, A.J.; Jayawardena, K.; Hemingway, J. Purification and characterization of a carboxylesterase involved in insecticide resistance from the mosquito Culex quinquefasciatus. Biochem. J. 1992, 287, 355-360. [CrossRef]

91. Vaughan, A.; Hemingway, J. Mosquito carboxylesterase Est alpha 2(1) (A2). Cloning and sequence of the full-length cDNA for a major insecticide resistance gene worldwide in the mosquito Culex quinquefasciatus. J. Biol. Chem. 1995, 270, 17044-17049. [CrossRef]

92. Vaughan, A.; Hawkes, N.; Hemingway, J. Co-amplification explains linkage disequilibrium of two mosquito esterase genes in insecticide-resistant Culex quinquefasciatus. Biochem. J. 1997, 325, 359-365. [CrossRef]

93. Bisset, J.; Rodriguez, M.; Soca, A.; Pasteur, N.; Raymond, M. Cross-resistance to pyrethroid and organophosphorus insecticides in the southern house mosquito (Diptera:Culicidae) from Cuba. J. Med. Entomol. 1997, 34, 244-246. [CrossRef] 
94. Liu, H.; Cupp, E.W.; Micher, K.M.; Guo, A.; Liu, N. Insecticide resistance and cross-resistance in Alabama and Florida strains of Culex quinquefasciatus. J. Med. Entomol. 2004, 41, 408-413. [CrossRef]

95. Yunta, C.; Hemmings, K.; Stevenson, B.; Koekemoer, L.L.; Matambo, T.; Pignatelli, P.; Voice, M.; Nász, S.; Paine, M.J.I. Crossresistance profiles of malaria mosquito $\mathrm{P} 450$ s associated with pyrethroid resistance against WHO insecticides. Pestic. Biochem. Physiol. 2019, 161, 61-67. [CrossRef]

96. Guillemaud, T.; Lenormand, T.; Bourguet, D.; Chevillon, C.; Pasteur, N.; Raymond, M. Evolution of Resistance in Culex pipiens: Allele Replacement and Changing Environment. Evolution 1998, 52, 443-453. [CrossRef]

97. Schechtman, H.; Souza, M.O. Costly inheritance and the persistence of insecticide resistance in Aedes aegypti populations. PLoS ONE 2015, 10, e0123961. [CrossRef] [PubMed]

98. Laxmishree, C.; Nandita, S. Botanical pesticides-A major alternative to chemical pesticides: A review. Int. J. Life Sci. 2017, 5, 722-729.

99. Thakore, Y. The biopesticide market for global agricultural use. Ind. Biotechnol. 2006, 2, 194-208. [CrossRef]

100. Prabha, S.; Yadav, A.; Kumar, A.; Yadav, A.; Yadav, H.K.; Kumar, S.; Kumar, R. Biopesticides-An alternative and eco-friendly source for the control of pests in agricultural crops. Plant Arch. 2016, 16, 902-906.

101. Ohia, C.M.D.; Ana, G.R.E.E. Bio-insecticides: The one-health response to mosquito-borne diseases of public health importance. J. Biol. Agric. Healthc. 2015, 5, 22-26.

102. Dara, S.K. Insect Resistance to Biopesticides. Available online: https://ucanr.edu/blogs/blogcore/postdetail.cfm?postnum=25819 (accessed on 23 November 2021).

103. Tyagi, B.K. Advances in Vector Mosquito Control Technologies, with Particular Reference to Herbal Products. In Herbal Insecticides, Repellents and Biomedicines: Effectiveness and Commercialization; Veer, V., Gopalakrishnan, R., Eds.; Springer: New Delhi, India, 2016; pp. 1-11.

104. Shaalan, E.A.S.; Canyonb, D.; Younesc, M.W.F.; Abdel-Wahaba, H.; Mansoura, A.H. A review of botanical phytochemicals with mosquitocidal potential. Environ. Int. 2005, 3, 1149-1166. [CrossRef] [PubMed]

105. Souto, A.L.; Sylvestre, M.; Tölke, E.D.; Tavares, J.F.; Barbosa-Filho, J.M.; Cebrián-Torrejón, G. Plant-Derived Pesticides as an Alternative to Pest Management and Sustainable Agricultural Production: Prospects, Applications and Challenges. Molecules 2021, 26, 4835. [CrossRef]

106. Sharma, P.; Mohan, L.; Srivastava, C.N. Phytoextract-induced developmental deformities in malaria vector. Bioresour. Technol. 2006, 97, 1599-1604. [CrossRef] [PubMed]

107. Al-Mekhlafi, F.A. Larvicidal, ovicidal activities and histopathological alterations induced by Carum copticum (Apiaceae) extract against Culex pipiens (Diptera: Culicidae). Saudi J. Biol. Sci. 2018, 25, 52-56. [CrossRef]

108. Senthil-Nathan, S. A review of resistance mechanisms of synthetic insecticides and botanicals, phytochemicals, and essential oils as alternative larvicidal agents against mosquitoes. Front. Physiol. 2020, 10, 1591. [CrossRef]

109. Syed, Z.; Leal, W.S. Mosquitoes smell and avoid the insect repellent DEET. Proc. Natl. Acad. Sci. USA 2008, 105, 13598-13603. [CrossRef]

110. Dickens, J.C.; Bohbot, J.D. Mini review: Mode of action of mosquito repellents. Pestic. Biochem. Physiol. 2013, 106, $149-155$. [CrossRef]

111. Pavela, R.; Benelli, G. Ethnobotanical knowledge on botanical repellents employed in the African region against mosquito vectors-A review. Exp. Parasitol. 2016, 167, 103-108. [CrossRef]

112. Maia, M.F.; Moore, S.J. Plant-based insect repellents: A review of their efficacy, development and testing. Malar. J. 2011,10, S11. [CrossRef] [PubMed]

113. Nagegowda, D.A. Plant volatile terpenoid metabolism: Biosynthetic genes, transcriptional regulation and subcellular compartmentation. FEBS Lett. 2010, 584, 2965-2973. [CrossRef] [PubMed]

114. Isman, M.B.; JunHyung, T. Inhibition of acetylcholinesterase by essential oils and monoterpenoids: A relevant mode of action for insecticidal essential oils? Biopestic. Int. 2017, 13, 71-78.

115. Jankowska, M.; Rogalska, J.; Wyszkowska, J.; Stankiewicz, M. Molecular targets for components of essential oils in the insect nervous system-A review. Molecules 2018, 23, 34. [CrossRef] [PubMed]

116. Pavela, R. Essential oils for the development of eco-friendly mosquito larvicides: A review. Ind. Crops Prod. 2015, 76, 174-187. [CrossRef]

117. Houghton, P.J.; Ren, Y.; Howes, M.J. Acetylcholinesterase inhibitors from plants and fungi. Nat. Prod. Rep. 2006, 23, 181-199. [CrossRef]

118. Abdelgaleil, S.A.; Mohamed, M.I.; Badawy, M.E.; El-arami, S.A. Fumigant and contact toxicities of monoterpenes to Sitophilus oryzae (L.) and Tribolium castaneum (Herbst) and their inhibitory effects on acetylcholinesterase activity. J. Chem. Ecol. 2009, 35, 518-535. [CrossRef]

119. Hideyuki, T.; Mitsuo, M. Inhibition of acetylcholinesterase activity by essential oil from Bergamot. Koryo Terupen oyobi Seiyu Kagaku ni Kansuru Toronkai Koen Yoshishu 2001, 45, 435-436.

120. Enan, E. Insecticidal activity of essential oils: Octopaminergic sites of action. Comp. Biochem. Physiol. C Toxicol. 2001, 130, 325-337. [CrossRef] 
121. Kostyukovsky, M.; Rafaeli, A.; Gileadi, C.; Demchenko, N.; Shaaya, E. Activation of octopaminergic receptors by essential oil constituents isolated from aromatic plants: Possible mode of action against insect pests. Pest Manag. Sci. 2002, 58, 1101-1106. [CrossRef] [PubMed]

122. Li, A.S.; Iijima, A.; Huang, J.; Li, Q.X.; Chen, Y. Putative Mode of Action of the Monoterpenoids Linalool, Methyl Eugenol, Estragole, and Citronellal on Ligand-Gated Ion Channels. Engineering 2020, 6, 541-545. [CrossRef]

123. Bloomquist, J.R. Chloride channels as tools for developing selective insecticides. Arch. Insect Biochem. Physiol. 2003, 54, 145-156. [CrossRef]

124. Bekele, D. Review on insecticidal and repellent activity of plant products for malaria mosquito control. Biomed. Res. Rev. 2018, 2, 1-7. [CrossRef]

125. Jaenson, T.G.; Pålsson, K.; Borg-Karlson, A.K. Evaluation of extracts and oils of mosquito (Diptera: Culicidae) repellent plants from Sweden and Guinea-Bissau. J. Med. Entomol. 2006, 43, 113-119. [CrossRef]

126. Gillij, Y.G.; Gleiser, R.M.; Zygadlo, J.A. Mosquito repellent activity of essential oils of aromatic plants growing in Argentina. Bioresour. Technol. 2008, 99, 2507-2515. [CrossRef]

127. Pandey, S.K.; Upadhyay, S.; Tripathi, A.K. Insecticidal and repellent activities of thymol from the essential oil of Trachyspermum ammi (Linn) Sprague seeds against Anopheles stephensi. Parasitol. Res. 2009, 105, 507-512. [CrossRef]

128. Park, B.S.; Choi, W.S.; Kim, J.H.; Kim, K.H.; Lee, S.E. Monoterpenes from thyme (Thymus vulgaris) as potential mosquito repellents. J. Am. Mosq. Control Assoc. 2005, 21, 80-83. [CrossRef]

129. Pavela, R.; Vrchotová, N.; Tříska, J. Mosquitocidal activities of thyme oils (Thymus vulgaris L.) against Culex quinquefasciatus (Diptera: Culicidae). Parasitol. Res. 2009, 105, 1365-1370. [CrossRef] [PubMed]

130. Pitarokili, D.; Michaelakis, A.; Koliopoulos, G.; Koliopoulos, G.; Giatropoulos, A.; Tzakouet, O. Chemical composition, larvicidal evaluation, and adult repellency of endemic Greek Thymus essential oils against the mosquito vector of West Nile virus. Parasitol. Res. 2011, 109, 425-430. [CrossRef] [PubMed]

131. Michaelakis, A.; Theotokatos, S.A.; Koliopoulos, G.; Chorianopoulos, N.G. Essential oils of Satureja species: Insecticidal effect on Culex pipiens larvae (Diptera: Culicidae). Molecules 2007, 12, 2567-2578. [CrossRef] [PubMed]

132. Evergetis, E.; Bellini, R.; Balatsos, G.; Michaelakis, A.; Carrieri, M.; Veronesi, R.; Papachristos, D.P.; Puggioli, A.; Kapsaski-Kanelli, V.-N.; Haroutounian, S.A. From Bio-Prospecting to Field Assessment: The Case of Carvacrol Rich Essential Oil as a Potent Mosquito Larvicidal and Repellent Agent. Front. Ecol. Evol. 2018, 6, 204. [CrossRef]

133. Cheng, S.S.; Liu, J.Y.; Tsai, K.H.; Chen, W.J.; Chang, S.T. Chemical composition and mosquito larvicidal activity of essential oils form leaves of different Cinnamonum osmophloem provenances. J. Agric. Food Chem. 2004, 52, 4395-4400. [CrossRef] [PubMed]

134. Tabari, M.A.; Youssefi, M.R.; Esfandiari, A.; Benelli, G. Toxicity of $\beta$-citronellol, geraniol and linalool from Pelargonium roseum essential oil against the West Nile and filariasis vector Culex pipiens (Diptera: Culicidae). Res. Vet. Sci. 2017, 114, 36-40. [CrossRef]

135. Andrade-Ochoa, S.; Sánchez-Aldana, D.; Chacón-Vargas, K.F.; Rivera-Chavira, B.E.; Sánchez-Torres, L.E.; Camacho, A.D.; Nogueda-Torres, B.; Nevárez-Moorillón, G.V. Oviposition Deterrent and Larvicidal and Pupaecidal Activity of Seven Essential Oils and their Major Components against Culex quinquefasciatus Say (Diptera: Culicidae): Synergism-antagonism Effects. Insects 2018, 9, 25. [CrossRef]

136. Govindarajan, M.; Benelli, G. Artemisia absinthium-borne compounds as novel larvicides: Effectiveness against six mosquito vectors and acute toxicity on non-target aquatic organisms. Parasitol. Res. 2016, 115, 4649-4661. [CrossRef]

137. Vera, S.S.; Zambrano, D.F.; Méndez-Sanchez, S.C.; Rodríguez-Sanabria, F.; Stashenko, E.E.; Luna, J.E.D. Essential oils with insecticidal activity against larvae of Aedes aegypti (Diptera: Culicidae). Parasitol. Res. 2014, 113, 2647-2654. [CrossRef]

138. Warikoo, R.; Wahab, N.; Kumar, S. Oviposition-altering and ovicidal potentials of five essential oils against female adults of the dengue vector, Aedes aegypti L. Parasitol. Res. 2011, 109, 1125-1131. [CrossRef]

139. Manh, H.D.; Hue, D.T.; Hieu, N.T.T.; Tuyen, D.T.T.; Tuyet, O.T. The Mosquito larvicidal activity of essential oils from Cymbopogon and Eucalyptus Species in Vietnam. Insects 2020, 11, 128. [CrossRef] [PubMed]

140. Gnankiné, O.; Bassolé, I.H.N. Essential oils as an alternative to pyrethroids' resistance against Anopheles species complex giles (Diptera: Culicidae). Molecules 2017, 22, 1321. [CrossRef]

141. Bassolé, I.H.N.; Guelbeogo, W.M.; Nébié, R.; Costantini, C.; Sagnon, N.; Kabore, Z.I.; Traoré, S.A. Ovicidal and larvicidal activity against Aedes aegypti and Anopheles gambiae complex mosquitoes of essential oils extracted from three spontaneous plants of Burkina Faso. Parassitologia 2003, 45, 23-26. [PubMed]

142. Cantrell, C.L.; Jones, A.M.; Ali, A. Isolation and Identification of Mosquito (Aedes aegypti) Biting-Deterrent Compounds from the Native American Ethnobotanical Remedy Plant Hierochloë odorata (Sweetgrass). J. Agric. Food Chem. 2016, 64, 8352-8358. [CrossRef]

143. Abbassy, M.A.; Abdelgaleil, S.A.; Rabie, R.Y. Insecticidal and synergistic effects of Majorana hortensis essential oil and some of its major constituents. Entomol. Exp. Appl. 2009, 131, 225-232. [CrossRef]

144. Osanloo, M.; Sedaghat, M.M.; Esmaeili, F.; Amani, A. Larvicidal activity of essential oil of Syzygium aromaticum (Clove) in comparison with its major constituent, eugenol, against Anopheles stephensi. J. Arthropod Borne Dis. 2018, 12, 361-369.

145. Dhinakaran, S.R.; Mathew, N.; Munusamy, S. Synergistic terpene combinations as larvicides against the Dengue vector Aedes aegypti Linn. Drug Dev. Res. 2019, 80, 791-799. [CrossRef]

146. Odalo, J.O.; Omolo, M.O.; Malebo, H.; Angira, J.; Njeru, P.M.; Ndiege, I.O.; Hassanali, A. Repellency of essential oils of some plants from the Kenyan coast against Anopheles gambiae. Acta Trop. 2005, 95, 210-218. [CrossRef] 
147. Schmutterer, H. Properties and potential of natural pesticides from the neem tree, Azadirachta indica. Annu. Rev. Entomol. 1990, 35, 271-297. [CrossRef]

148. Campos, E.V.; de Oliveira, J.L.; Pascoli, M.; de Lima, R.; Fraceto, L.F. Neem oil and crop protection: From now to the future. Front. Plant Sci. 2016, 7, 1494. [CrossRef]

149. Govindchari, T.R. Chemistry and biological investigation on Azadirachta indica (the neem tree). Curr. Sci. 1992, 63, 117-122.

150. Mordue, A.J.; Blackwell, A. Azadirachtin: An update. J. Insect Physiol. 1993, 11, 903-924. [CrossRef]

151. Sidhu, O.P.; Kumar, V.; Behl, H.M. Variability in neem (Azadirachta indica) with respect to azadirachtin content. J. Agric. Food Chem. 2003, 51, 910-915. [CrossRef] [PubMed]

152. Morgan, E.D. Azadirachtin, a scientific gold mine. Bioorg. Med. Chem. 2009, 17, 4096-4105. [CrossRef] [PubMed]

153. Benelli, G.; Murugan, K.; Panneerselvam, C.; Madhiyazhagan, P.; Conti, B.; Nicoletti, M. Old ingredients for a new recipe? Neem cake, a low-cost botanical by-product in the fight against mosquito-borne diseases. Parasitol. Res. 2015, 114, 391-397. [CrossRef] [PubMed]

154. Dwivedi, N. Neem: Present status and future prospects. Plant Arch. 2008, 8, 17-22.

155. Beckage, N.E. Insect growth regulators. In Biological and Biotechnological Control of Insect Pests; Rechcigl, J.E., Rechcigl, N.A., Eds.; CRC Press LLC: Boca Raton, FL, USA, 2000; pp. 123-137.

156. Mulla, M.S.; Su, M. Activity and biological effects of neem products against arthropods of medical and veterinary importance. $J$. Am. Mosq. Control Assoc. 1999, 15, 133-152. [PubMed]

157. Nisbet, A.J. Azadirachtin from the neem tree Azadirachta indica: Its action against insects. An. Soc. Entomol. Bras. 2000, $29,615-632$.

158. Schmutterer, H. The Neem Tree, Azadirachta indica (A. Juss) and Other Meliaceous Plants: Source of Unique Natural Products for Integrated Pest Management, Medicine, Industry and Other Purposes; VCH: Weinheim, Germany, 1995; p. 696.

159. Lucantoni, L.; Giusti, F.; Cristofaro, M.; Pasqualini, L.; Esposito, F.; Lupetti, P.; Habluetzel, A. Effects of a neem extract on blood feeding, oviposition and oocyte ultrastructure in Anopheles stephensi Liston (Diptera: Culicidae). Tissue Cell 2006, 38, 361-371. [CrossRef]

160. Isman, M.B. Botanical insecticides, deterrents and repellents in modern agriculture and an increasingly regulated world. Annu. Rev. Entomol. 2006, 51, 45-66. [CrossRef]

161. Dua, V.K.; Pandey, A.C.; Raghavendra, K.; Gupta, A.; Sharma, T.; Dash, A.P. Larvicidal activity of neem oil (Azadirachta indica) formulation against mosquitoes. Malar. J. 2009, 8, 1-6. [CrossRef] [PubMed]

162. Ayinde, A.A.; Morakinyo, O.M.; Sridhar, M.K.C. Repellency and larvicidal activities of Azadirachta indica seed oil on Anopheles gambiae in Nigeria. Heliyon 2020, 6, e03920. [CrossRef] [PubMed]

163. Maheswaran, R.; Ignacimuthu, S. A novel herbal formulation against dengue vector mosquitoes Aedes aegypti and Aedes albopictus. Parasitol. Res. 2012, 110, 1801-1813. [CrossRef] [PubMed]

164. Senthil-Nathan, S.; Kalaivani, K.; Muruganb, K. Effects of neem limonoids on the malaria vector Anopheles stephensi Liston (Diptera: Culicidae). Acta Trop. 2005, 96, 47-55. [CrossRef]

165. Vatandoost, H.; Vaziri, V.M. Larvicidal activity of a neem tree extract (Neemarin) against mosquito larvae in the Islamic Republic of Iran. East. Mediterr. Health J. 2004, 10, 573-581. [CrossRef]

166. Grdiša, M.; Gršić, K. Botanical insecticides in plant protection. Agric. Conspec. Sci. 2013, 78, 85-93.

167. Pavela, R. History, presence and perspective of using plant extracts as commercial botanical insecticides and farm products for protection against insects-A review. Plant Prot. Sci. 2016, 52, 229-241.

168. Osimitz, T.G.; Sommers, N.; Kingston, R. Human exposure to insecticide products containing pyrethrins and piperonyl butoxide (2001-2003). Food Chem. Toxicol. 2009, 47, 1406-1415. [CrossRef]

169. Duchon, S.; Bonnet, J.; Marcombe, S.; Zaim, M.; Corbel, V. Pyrethrum: A mixture of natural pyrethrins has potential for malaria vector control. J. Med. Entomol. 2009, 46, 516-522. [CrossRef]

170. Liu, F.; Wang, Q.; Xu, P.; Andreazza, F.; Valbon, W.R.; Bandason, E.; Dong, K. A dual-target molecular mechanism of pyrethrum repellency against mosquitoes. Nat. Commun. 2021, 12, 2553. [CrossRef]

171. Gutiérrez-Grijalva, E.P.; López-Martínez, L.X.; Contreras-Angulo, L.A.; Elizalde-Romero, C.A.; Heredia, J.B. Plant Alkaloids: Structures and Bioactive Properties. In Plant-Derived Bioactives; Swamy, M.K., Ed.; Springer: Singapore, $2020 ;$ pp. 85-117.

172. Ahmed, N.; Alam, M.; Saeed, M.; Ullah, H.; Iqbal, T.; Al-Mutairi, K.A.; Shahjeer, K.; Ullah, R.; Ahmed, S.; Ahmed, N.A.A.H.; et al Botanical insecticides are a non-toxic alternative to conventional pesticides in the control of insects and pests. In Global Decline of Insects; El-Shafie, H., Ed.; IntechOpen: London, UK, 2021.

173. Secoy, D.M.; Smith, A.E. Use of plants in control of agricultural and domestic pests. Econ. Bot. 1983, 37, 28-57. [CrossRef]

174. Chowański, S.; Adamski, Z.; Marciniak, P.; Rosiński, G.; Büyükgüzel, E.; Büyükgüzel, K.; Bufo, S.A. A review of bioinsecticidal activity of Solanaceae alkaloids. Toxins 2016, 8, 60. [CrossRef] [PubMed]

175. Balachandran, C.; Anbalagan, S.; Kandeepan, C.; Nagendran, N.A.; Jayakumar, M.; Abd Allah, E.F.; Alqarawi, A.A.; Hashem, A.; Baskar, K. Molecular docking studies of natural alkaloids as acetylcholinesterase (ache1) inhibitors in Aedes aegypti. J. Asia Pac. Entomol. 2021, 24, 645-652. [CrossRef]

176. Elimam, A.M.; Elmalik, K.H.; Ali, F.S. Larvicidal, adult emergence inhibition and oviposition deterrent effects of foliage extract from Ricinus communis L. against Anopheles arabiensis and Culex quinquefasciatus in Sudan. Trop. Biomed. 2009, 26, 130-139. 
177. Wachira, S.W.; Omar, S.; Jacob, J.W.; Wahome, M.; Alborn, H.T.; Spring, D.R.; Masiga, D.; Torto, B. Toxicity of six plant extracts and two pyridone alkaloids from Ricinus communis against the malaria vector Anopheles gambiae. Parasites Vectors 2014, 7, 1-8. [CrossRef]

178. Kim, S.I.; Ahn, Y.J. Larvicidal activity of lignans and alkaloid identified in Zanthoxylum piperitum bark toward insecticidesusceptible and wild Culex pipiens pallens and Aedes aegypti. Parasites Vectors 2017, 10, 1-10. [CrossRef] [PubMed]

179. Liu, Z.L.; Liu, Q.Z.; Du, S.S.; Deng, Z.W. Mosquito larvicidal activity of alkaloids and limonoids derived from Evodia rutaecarpa unripe fruits against Aedes albopictus (Diptera: Culicidae). Parasitol. Res. 2012, 111, 991-996. [CrossRef] [PubMed]

180. Velu, K.; Elumalai, D.; Hemalatha, P.; Babu, M.; Janaki, A.; Kaleena, P.K. Phytochemical screening and larvicidal activity of peel extracts of Arachis hypogaea against chikungunya and malarial vectors. Int. J. Mosq. Res. 2015, 2, 1-8.

181. Jufri, M.; Irmayanti, E.; Gozan, M. Formulation of tobacco-based mosquito repellent to avoid dengue fever. Int. J. Pharmtech. Res. 2016, 9, 140-145.

182. Perumalsamy, H.; Jang, M.J.; Kim, J.R.; Kadarkarai, M.; Ahn, Y.J. Larvicidal activity and possible mode of action of four flavonoids and two fatty acids identified in Millettia pinnata seed toward three mosquito species. Parasites Vectors 2015, 8, 237. [CrossRef]

183. Ningrum, D.S.; Wijayanti, S.P.M.; Kuswanto, K. Mosquito larvacidal activity of Zingiber Montanum rhizome extract against Aedes aegypti larvae. Balaba 2019, 15, 33-40. [CrossRef]

184. Yenesew, A.; Twinomuhwezi, H.; Kabaru, J.M.; Akala, H.M.; Kiremire, B.T.; Heydenreich, M.; Peter, M.G.; Eyase, F.L.; Waters, N.C.; Walsh, D.S. Antiplasmodial and larvicidal flavonoids from Derris trifoliata. Bull. Chem. Soc. Ethiop. 2009, $23,409-414$. [CrossRef]

185. Zubairi, S.I.; Sarmidi, M.R.; Aziz, R.A. A preliminary study on mosquito larvicidal efficacy of rotenone extracted from Malaysia Derris sp. J. Teknol. 2015, 76, 275-279. [CrossRef]

186. WHO. Guidelines for Laboratory and Field Testing of Mosquito Larvicides; World Health Organization: Geneva, Switzerland, 2005.

187. WHO. Guidelines for Testing Mosquito Adulticides for Indoor Residual Spraying and Treatment of Mosquito Nets; World Health Organization: Geneva, Switzerland, 2006.

188. WHO. Guidelines for Laboratory and Field-Testing of Long-Lasting Insecticidal Nets; World Health Organization: Geneva, Switzerland, 2013.

189. WHO. Techniques to Detect Insecticide Resistance Mechanisms (Field and Laboratory Manual); World Health Organization: Geneva, Switzerland, 1998.

190. Tehri, K.; Singh, N. The role of botanicals as green pesticides in integrated mosquito management-A review. Int. J. Mosq. Res. 2015, 2, 18-23.

191. Namias, A.; Jobe, N.B.; Paaijmans, K.P.; Huijben, S. The need for practical insecticide-resistance guidelines to effectively inform mosquito-borne disease control programs. eLife 2021, 10, e65655. [CrossRef]

192. BioWorks. Available online: https://bioworksinc.com/wp-content/uploads/products/shared/resistance-to-biopesticides.pdf (accessed on 20 January 2022).

193. Regnault-Roger, C.; Vincent, C.; Arnason, J.T. Essential oils in insect control: Low-risk products in a high-stakes world. Annu. Rev. Entomol. 2012, 57, 405-424. [CrossRef] [PubMed]

194. Aïzoun, N.; Aïpon, R.; Azondekon, R.; Gnanguenon, V.; Osse, R.; Padonou, G.G.; AkogbÃeto, M. Centre for Disease Control and Prevention (CDC) bottle bioassay: A real complementary method to World Health Organization (WHO) susceptibility test for the determination of insecticide susceptibility in malaria vectors. J. Parasitol. Vector Biol. 2014, 6, 42-47.

195. Centers for Disease Control. Available online: https://www.cdc.gov/malaria/resources/pdf/fsp/ir_manual/ir_cdc_bioassay_ en.pdf (accessed on 20 January 2022).

196. Zhu, K.Y. RNA interference: A powerful tool in entomological research and a novel approach for insect pest management. Insect Sci. 2013, 20, 1-3. [CrossRef] [PubMed]

197. Airs, P.M.; Bartholomay, L.C. RNA Interference for Mosquito and Mosquito-Borne Disease Control. Insects 2017, 8, 4. [CrossRef]

198. Zhu, F.; Cui, Y.; Walsh, D.B.; Lavine, L.C. Application of RNAi toward insecticide resistance management. In Short Views on Insect Biochemistry and Molecular Biology, 1st ed.; Chandrasekar, R., Tyagi, B.K., Gui, Z.Z., Reeck, G.R., Eds.; International Book Mission, Academic Publisher: Manhattan, NY, USA, 2014; Chapter 27; Volume 2, pp. 595-619.

199. Munawar, K.; Alahmed, A.M.; Khalil, S.M.S. Delivery methods for RNAi in mosquito larvae. J. Insect Sci. 2020, 20, 1-8. [CrossRef]

200. Singh, A.D.; Wong, S.; Ryan, C.P.; Whyard, S. Oral delivery of double-stranded RNA in larvae of the yellow fever mosquito, Aedes aegypti: Implications for pest mosquito control. J. Insect Sci. 2013, 13, 1-18. [CrossRef] [PubMed]

201. Blitzer, E.J.; Vyazunova, I.; Lan, Q. Functional analysis of AeSCP-2 using gene expression knockdown in the yellow fever mosquito, Aedes aegypti. Insect Mol. Biol. 2005, 14, 301-307. [CrossRef]

202. Zhang, X.; Zhang, J.; Zhu, K.Y. Chitosan/double-stranded RNA nanoparticle-mediated RNA interference to silence chitin synthase genes through larval feeding in the African malaria mosquito (Anopheles gambiae). Insect Mol. Biol. 2010, 19, 683-693. [CrossRef]

203. Mafra-Neto, A.; de Lame, F.M.; Fettig, C.J.; Munson, A.S.; Perring, T.M.; Stelinski, L.L.; Stoltman, L.; Mafra, L.E.J.; Borges, R.; Vargas, R.I. Manipulation of Insect Behavior with Specialized Pheromone and Lure Application Technology (SPLAT ${ }^{\circledR}$ ). In Natural Products for Pest Management; Beck, J., Coats, J., Duke, S., Koivunen, M., Eds.; ACS Publications: Washington, DC, USA, 2013; Chapter 4; pp. 31-58.

204. Schorkopf, D.L.P.; Spanoudis, C.G.; Mboera, L.E.; Mafra-Neto, A.; Ignell, R.; Dekker, T. Combining attractants and larvicides in biodegradable matrices for sustainable mosquito vector control. PLoS Negl. Trop. Dis. 2016, 10, e0005043. [CrossRef] [PubMed] 
205. Isman, M.B.; Miresmailli, S.; Machial, C. Commercial opportunities for pesticides based on plant essential oils in agriculture, industry and consumer products. Phytochem. Rev. 2011, 10, 197-204. [CrossRef]

206. Specos, M.M.; García, J.J.; Tornesello, J.; Marino, P.; Vecchia, M.D.; Tesoriero, M.D.; Hermida, L.G. Microencapsulated citronella oil for mosquito repellent finishing of cotton textiles. Trans. R. Soc. Trop. Med. Hyg. 2010, 104, 653-658. [CrossRef] [PubMed]

207. Grancaric, A.M.; Laird, K.; Botteri, L.; Shen, J.; Laatikainen, K. Microencapsulation for improved mosquitoes' repellent efficacy of cotton fabrics. IOP Conf. Ser. Mater. Sci. Eng. 2020, 827, 012056. [CrossRef]

208. Specos, M.M.; Garcia, J.J.; Gutierrez, A.C.; Hermida, L.G. Application of microencapsulated biopesticides to improve repellent finishing of cotton fabrics. J. Text. Inst. 2017, 108, 1454-1460. [CrossRef]

209. Pardini, F.; Iregui, Á.; Faccia, P.; Amalvy, J.; González, A.; Irusta, L. Development and characterization of electrosprayed microcaspules of poly $\varepsilon$-caprolactone with citronella oil for mosquito-repellent application. Int. J. Polym. Anal. Charact. 2021, 26, 497-516. [CrossRef]

210. Sakulkua, U.; Nuchuchuaa, O.; Uawongyartb, N.; Puttipipatkhachornc, S.; Soottitantawatd, A.; Ruktanonchaia, U. Characterization and mosquito repellent activity of citronella oil nanoemulsion. Int. J. Pharm. Nanotechnol. 2009, 372, 105-111. [CrossRef]

211. Pant, M.; Dubey, S.; Raza, S.K.; Patanjali, P.K. Encapsulation of neem and karanja oil mixture for synergistic as well as larvicidal activity for mosquito control. J. Sci. Ind. Res. 2012, 71, 348-352.

212. Schleier, J.J., III; Peterson, R.K.D. Pyrethrins and pyrethroid insecticides. In Green Trends in Insect Control; Lopez, O., FernandezBolanos, J., Eds.; Royal Society of Chemistry: Cambridge, UK, 2011; Chapter 3; pp. 94-131.

213. Veronesi, R.; Gentile, G.; Carrieri, M.; Maccagnani, B.; Stermieri, L.; Bellini, R. Seasonal pattern of daily activity of Aedes caspius, Aedes detritus, Culex modestus, and Culex pipiens in the Po Delta of northern Italy and significance for vector-borne disease risk assessment. J. Vector Ecol. 2012, 37, 49-61. [CrossRef]

214. Silva, L.L.S.; Silva, S.C.C.; de Oliveira, A.P.S.; Nascimento, J.D.S.; Silva, E.O.; Coelho, L.C.B.B.; Neto, P.J.R.; Navarro, D.M.D.A.F.; Napoleão, T.H.; Paiva, P.M.G. Effects of a solid formulation containing lectin-rich fraction of Moringa oleifera seeds on egg hatching and development of Aedes aegypti larvae. Acta Trop. 2021, 214, 105789. [CrossRef] 